Piotr Jeżowski

\title{
POLITYKA KLIMATYCZNA UE A ROZWÓJ POLSKIEJ ENERGETYKI KONWENCJONALNEJ
}

\section{Wprowadzenie}

Regulacje klimatyczno-energetyczne UE wywierają ogromny wpływ na kierunki rozwoju polskiej energetyki konwencjonalnej, energetyki odnawialnej (OZE) i energetyki jądrowej, a także na inne postrzeganie gazownictwa i efektywności energetycznej. Polska stoi przed wielkimi wyzwaniami w zakresie rozwoju energetyki zgodnego z zasadami rozwoju zrównoważonego i polityki klimatycznej UE. W szczególności wysokie są koszty ambicji klimatycznych UE, które w sposób nieproporcjonalny do innych państw UE obciążają naszą energetykę i gospodarkę, przede wszystkim ze względu na jednostronność polskiego bilansu energetycznego na poziomie krajowego zużycia energii pierwotnej. Polska musi ponieść wielki wysiłek, aby przystosować się do wymogów, jakie narzucają stare i nowe regulacje UE.

W sytuacji ostrego kursu UE na dekarbonizację gospodarki i rosnące wymogi emisyjne energetyka konwencjonalna w Polsce ma ograniczone możliwości rozwoju. Do tego dochodzi zapóźnienie rozwoju infrastruktury energetycznej w zakresie źródeł energii elektrycznej i cieplnej, sieci przesyłowych i rozdzielczych. Zapóźnienie obejmuje także energetykę odnawialną, która znajduje się in statu nascendi. Również poziom efektywności energetycznej pozostawia wiele do życzenia zarówno w zakresie sprawności przetwarzania nośników energii, jak i stanu oraz sprawności odbiorników energetycznych i urządzeń kontrolno-pomiarowych. Zbieg tych okoliczności otwiera przestrzeń dla powtarzających się konfliktów Polski z UE.

Gospodarkę czeka wielki wysiłek ekonomiczny, aby zmodernizować konwencjonalną elektroenergetykę i ciepłownictwo oraz przeprowadzić je bezpiecznie przez następne lata. $W$ przeciwnym razie może dojść do zagrożenia bezpieczeństwa dostaw energii, ponieważ ani OZE, ani poprawa efektywności nie wystarczą na uzupełnienie ubytku dostaw ze źródeł konwencjonalnych. Modernizacja wymaga pokonania nie 
tylko barier ekonomicznych, organizacyjnych i technicznych, lecz także uzyskania społecznej akceptacji przemian energetyki konwencjonalnej.

Autor podejmuje główne problemy funkcjonowania i rozwoju polskiej energetyki konwencjonalnej, ze szczególnym uwzględnieniem technicznych i ekonomiczno-społecznych skutków handlu emisjami $\mathrm{CO}_{2}$ i dyrektyw emisyjnych oraz oceny potrzeb finansowych związanych z modernizacją i rozwojem źródeł oraz sieci ${ }^{1}$. Problemy polskiej energetyki konwencjonalnej zostaną pokazane na tle uwarunkowań zewnętrznych, czyli regulacji klimatyczno-energetycznych UE obejmujących „stare” dyrektywy emisyjne, pakiet 3x20 i najnowsze zmiany pułapów emisyjnych. Autor nie podejmuje problemów gazownictwa, odnawialnych źródeł energii (OZE), efektywności energetycznej i funkcjonowania rynków energii.

\section{Polityka klimatyczno-energetyczna UE a stan polskiej energetyki}

Polityka energetyczna UE stanowi zmieniający się zespół regulacji systemu prawa, struktur organizacyjnych, systemów regulacyjnych, instrumentów ochrony środowiska i klimatu, cen i taryf oraz mechanizmów ekonomiczno-finansowych. Polityka energetyczna UE stawia sobie następujące główne cele:

- zapewnienie krótko- i długookresowego bezpieczeństwa energetycznego oraz tworzenie wewnętrznego rynku gazu i energii elektrycznej ze zwiększeniem niezależności i uprawnień regulatorów energetyki,

- zapewnienie konkurencyjności gospodarki UE poprzez minimalizację cen energii w warunkach samofinansowania sektorów energetycznych,

- ochronę środowiska poprzez minimalizację szkodliwości technologii energetycznych dla środowiska i klimatu Ziemi,

- poprawę efektywności energetycznej².

Założenia ekologiczne i klimatyczne powodują, że polityka energetyczna UE jest w zasadzie częścią polityki ekologicznej UE, która uwzględnia zasady rozwoju zrównoważonego, to jest uznania nadrzędności wymogów ekologicznych w procesie rozwoju społeczno-gospodarczego, oraz wymagania dotyczące ochrony klimatu,

1 Opracowanie jest fragmentem badania statutowego Katedry Ekonomii Środowiska i Zasobów Naturalnych w 2010 r. pt. Współczesne uwarunkowania wdrażania rozwoju zrównoważonego. Europa a świat, cz. 3: Uwarunkowania rozwoju polskiej energetyki w świetle polityki klimatyczno-energetycznej Unii Europejskiej.

2 J. Chojnowski, Zapotrzebowanie na energie, efektywne jej wykorzystanie oraz ceny w Polsce i Unii Europejskiej, „Rynek Energii” 2007, nr 4; A. Lakomiak, Polityka ekologiczna państw Unii Europejskiej, „Rynek Energii” 2005, nr 12. 
związane z realizacją porozumienia z Kyoto, a uznające katastroficzne opinie pewnej części klimatologów. Polityki energetycznej i strategii rozwoju energetyki UE nie można rozpatrywać w oderwaniu od unijnej strategii rozwoju zrównoważonego oraz strategii ochrony klimatu.

UE jako promotor idei rozwoju zrównoważonego i obrońca klimatu Ziemi oraz lider OZE stawia energetyce coraz wyższe i ambitniejsze wymagania ekologiczne, klimatyczne i efektywnościowe. Ich spełnienie wiąże się z wysokimi kosztami przestawienia krajowych sektorów energetycznych na nowe tory. Przy tym nie są to zadania i obciążenia równomiernie i sprawiedliwie rozłożone między państwa członkowskie. Ze względu na strukturę bilansu energetycznego Polska znajduje się tu w naprawdę trudnej sytuacji.

Podstawą wyjściową polityki energetycznej UE po 2000 r. były takie akty prawne i wytyczne ogólne o charakterze strategiczno-taktycznym, jak: Traktat karty energetycznej, Europejska karta energetyczna, białe księgi UE, Zielona ksiega 2000, raport Energia i transport 2000-2004, konkluzje prezydencji³. Jednak zasadnicze regulacje sektorów energetycznych w UE stanowią dyrektywy oraz rozporządzenia i decyzje. W szczególności do istotnych dla energetyki „starych” dyrektyw zaliczają się:

- dyrektywa 2003/54/EC o jednolitych zasadach wewnętrznego rynku energii elektrycznej, uchylająca dyrektywę 96/92/EC,

- dyrektywa 2003/55/EC o jednolitych zasadach wewnętrznego rynku gazu ziemnego, uchylająca dyrektywę 98/23/EC,

- dyrektywa 2005/89/EC o działaniach na rzecz zagwarantowania dostaw energii elektrycznej,

- dyrektywa 2003/30/WE w sprawie wspierania użycia w transporcie biopaliw lub innych paliw odnawialnych,

- dyrektywa 96/61/WE (directive concerning integrated pollution prevention and control - dyrektywa IPPC) w sprawie zintegrowanego zapobiegania i ograniczenia zanieczyszczeń, wprowadzająca pozwolenia zintegrowane dla większych instalacji, które są oparte na najlepszych dostępnych technikach (best available technics),

- dyrektywa 2001/80/WE (directive on the limitation of emissions from large combustion plants - dyrektywa LPC) w sprawie ograniczenia niektórych zanieczyszczeń powietrza atmosferycznego z dużych obiektów energetycznego spalania paliw, wprowadzająca niskie limity emisji $\mathrm{SO}_{2}, \mathrm{NO}_{\mathrm{x}}$ i pyłów dla instalacji energetycznych o mocy wyższej niż $50 \mathrm{MW}$,

3 M. Borgosz-Koczwara, K. Herlender, Bezpieczeństwo energetyczne a rozwój odnawialnych energii, „Energetyka” 2008, nr 3; A. Łakomiak, op.cit.; J. Malko, Energetyczna Strategia Unii Europejskiej, „Wokół Energetyki” 2006, nr 6. 
- dyrektywa 2001/81/EC (directive on national emision ceilings for certain atmospheric pollutants - dyrektywa NEC) w sprawie narodowych pułapów emisji zanieczyszczeń, wprowadzająca łączne limity emisji $\mathrm{SO}_{2}$ i $\mathrm{NO}_{\mathrm{x}}$ dla poszczególnych państw UE,

- dyrektywa 2003/87/WE (EU emission trading scheme - dyrektywa ETS) dotycząca zasad handlu emisjami gazów cieplarnianych, zmieniona dyrektywą łączącą 2004/101/EC (linking directive), wprowadzająca od 1 stycznia 2005 r. handel dwutlenkiem węgla $\left(\mathrm{CO}_{2}\right)$,

- dyrektywa 2001/77/WE (directive on the promotion of electricity produced from renewable energy sources - dyrektywa RES) w sprawie wspierania produkcji na rynku wewnętrznym energii elektrycznej wytwarzanej ze źródeł odnawialnych,

- dyrektywa 2004/8/WE (directive on the promotion of cogeneration based on useful heat demand - dyrektywa CHP) w sprawie wspierania kogeneracji (gospodarki skojarzonej) w oparciu o zapotrzebowanie na ciepło użytkowe na rynku wewnętrznym energii, zmieniająca dyrektywę 92/42/EWG.

Cztery pierwsze dyrektywy dotyczą w zasadzie organizacji rynków energetycznych i bezpieczeństwa energetycznego, pozostałe natomiast mają bardzo ścisły związek z energetyką konwencjonalną i innowacyjną ${ }^{4}$.

Od 2006r. UE wypracowuje nową politykę energetyczną o większej spójności niż poprzednia. Najważniejszymi dokumentami w tym zakresie były:

- Zielona ksiega 2006 o podtytule Europejska strategia na rzecz zrównoważonej, konkurencyjnej i bezpiecznej energii. Jest to formalny dokument początkujący nową politykę energetyczną, zakreślający i modyfikujący główne cele dotychczasowej polityki energetycznej UE nakierowane obecnie na wzrost konkurencyjności rynku energii, poprawę bezpieczeństwa dostaw energii oraz rozwój energetyki odnawialnej ograniczający wpływ na środowisko ${ }^{5}$.

- Pakiet klimatyczno-energetyczny (popularnie nazywany pakietem $3 \times 20$ ) przedstawiony do konsultacji przez Komisję Europejską 10 stycznia 2007 r. Stanowi on zestaw dokumentów dotyczących propozycji działań legislacyjnych i innych

4 Ponadto obowiązuje kilka dyrektyw regulujących efektywność energetyczną. Najważniejsze z nich to: - dyrektywa 2006/32/WE (energy services directive - dyrektywa ESD) w sprawie efektywności końcowego wykorzystania energii i usług energetycznych, uchylająca dyrektywę 93/76/EWG,

- dyrektywa 2005/32/WE ustanawiająca ogólne zasady ustalania wymogów dotyczących ekoprojektu dla produktów wykorzystujących energię,

- dyrektywa 2002/91/WE w sprawie charakterystyki energetycznej budynków.

Pakiet legislacyjny efektywności energetycznej uzupełnia dyrektywa w sprawie sprawności kotłów wody gorącej opalanych paliwem płynnym lub gazowym (92/42/EWG), dyrektywa dotycząca wyrobów budowlanych (89/106/EWG) oraz wiele dyrektyw poświęconych etykietowaniu efektywności energetycznej urządzeń AGD i urządzeń biurowych. Efektywność energetyczną promuje również dyrektywa CHP. J. Biedrzycki, P. Seklecki, Efektywność energetyczna w prawodawstwie wspólnotowym, „Biuletyn URE” 2007, nr 1.

5 S. Tokarski, J. Janikowski, Tworzenie polityki energetycznej Unii Europejskiej, „Koncern” - Gazeta PKE SA 2007, nr 11. 
w zakresie rynku energii elektrycznej i rynku energii gazowej, energii jądrowej, technologii energetycznych, w tym także mapy drogowej dla źródeł odnawialnych ${ }^{6}$. W istocie jest to skonkretyzowany zarys nowej europejskiej polityki energetycznej, określający cele do 2020 r. oraz cele dalszej perspektywy do 2050 r. ${ }^{7}$

- W marcu 2007 r. przyjęto trzy wiążące cele do 2020 r., to jest: redukcję gazów cieplarnianych o $20 \%$, wzrost udziału energii odnawialnej do $20 \%$ oraz oszczędność zużycia energii pierwotnej - 20\%. W styczniu 2008 r. KE opublikowała wchodzący w skład pakietu energetyczno-klimatycznego projekt zmienionej dyrektywy dotyczącej promocji źródeł odnawialnych (RES) ${ }^{8}$. Kierunkami działań realizującymi dyrektywę RES powinny być m.in. czyste technologie węglowe, technologie wychwytywania i magazynowania $\mathrm{CO}_{2}$ (carbon capture and storage, CCS), rozwój wewnętrznego rynku energii zgodny z rozwojem OZE oraz dążenie do rozerwania związku między rozwojem gospodarczym a degradacją środowiska9

Ostateczny kształt pakietu został przyjęty 23 kwietnia 2009 r. W ramach nowej polityki energetycznej UE przeprowadzono również zmiany wielu dotychczas obowiązujących dyrektyw, a mianowicie: nowelizację dyrektywy IPPC modyfikującą zapisy dyrektywy LPC, nowelizację dyrektywy NEC oraz nowelizację dyrektywy ETS (dyrektywa 2009/29/WE). Przyjęto również nową dyrektywę 2009/31/WE o wychwytywaniu i składowaniu dwutlenku węgla (directive on the carbon dioxide capture and storage - dyrektywa CCS $)^{10}$. W $2010 \mathrm{r}$. zakończono prace nad nową dyrektywą o emisjach przemysłowych (directive on industrial emissions - dyrektywa IED), zmieniającą radykalnie ustalenia dyrektywy LPC i dyrektywy IPPC.

Ogólnie można stwierdzić, że zmiany dyrektyw poszły wyraźnie w kierunku zaostrzenia wymogów ekologiczno-energetycznych oraz poszerzenia list instalacji podlegających regulacjom. Zmiany w dyrektywie ETS i w dyrektywie RES zobowiązywały elektrownie do pełnego wykupu giełdowego pozwoleń emisyjnych $\mathrm{CO}_{2}$ po 2012 r. oraz nałożyły na poszczególne państwa zróżnicowane cele wskaźnikowe OZE $^{11}$. Dla Polski ustalono na 2020 r. wskaźnik na poziomie $15 \%{ }^{12}$.

6 Ibidem.

7 Por. Europejska polityka energetyczna. Komunikat Komisji do Rady Europejskiej i Parlamentu Europejskiego, KOM (2007) 1, Bruksela, 10.01.2007.

8 Dyrektywa RES została przyjęta w 2009 r. jako dyrektywa 2009/28/WE.

9 A. Kowalska, Nowe dyrektywy UE dla obszaru elektroenergetyki, „Energia Elektryczna” 2008, nr 4.

${ }^{10}$ Formalnie ta dyrektywa ma ostateczną nazwę: Directive 2009/31/EC on the geological storage of carbon dioxide (o geologicznym składowaniu dwutlenku węgla).

${ }^{11}$ Cel 20\% odnosi się do Unii Europejskiej jako całości i ma zostać osiągnięty do 2020 r. Indywidualizacja wymagań wynika ze zróżnicowania implementacji pakietu w momencie jego tworzenia w poszczególnych państwach. Cele dotyczące OZE odnoszą się do energetyki sensu largo, a więc obejmują zarówno podsektor elektroenergetyczny, jak i podsektory ogrzewania i chłodzenia oraz transport.

12 S. Tokarski, J. Janikowski, Projekt nowej dyrektywy o źródłach odnawialnych, „Koncern” - Gazeta PKE SA 2008, nr 3. 
Ideologia pakietu $3 \times 20$ wychodzi z tego, że UE jest zmuszona do budowania swojej pozycji, opierając się na nowym modelu globalnej gospodarki, w którym sektory innowacyjnych technologii są kluczowym elementem wzrostu gospodarczego. Postawienie na innowacyjność w sektorze energetycznym ma pozwolić Europie na zbudowanie przewagi konkurencyjnej zarówno w stosunku do Stanów Zjednoczonych, jak i prężnie rozwijających się państw azjatyckich. Pomiędzy tymi globalnymi aktorami trwa wyścig o to, kto stanie się producentem produktów mających zaspokoić popyt w nowo kształtujących się sektorach. Technologie niskoemisyjne, w tym również CCS, mają stać się ważnym czynnikiem gospodarki innowacyjnej $\mathrm{UE}^{13}$. Problem jednak w tym, że nie wszyscy wielcy gracze globalni podzielają ducha polityki UE, co powoduje, że szanse zbytu technologii są skromne. Co więcej, np. Chiny same stają się poważnym producentem i eksporterem innowacyjnych produktów dla energetyki (panele słoneczne, małe i średnie turbiny wiatrowe nowej generacji). Co do Polski, to sugeruje się, że mamy unikalną szansę na wpisanie się w nurt innowacji i zaistnienia jako lider w dziedzinie CCS ${ }^{14}$. Dziś Polska partycypuje w globalnym rynku paneli słonecznych.

Zasadniczą słabą stroną pakietu jest brak skojarzenia z globalną polityką ekologiczną. De facto pakiet niewiele może zmienić w zakresie klimatu, ponieważ to, co Unia zrobi dla klimatu, nie ma znaczenia. Partycypacja UE w globalnej emisji $\mathrm{CO}_{2}$ jest bowiem niewielka (14-15\%), dużo niższa niż udział w gospodarce światowej (25\%). Kolejne szczyty Ziemi (Kopenhaga, Poznań) pokazały prawie zerową skuteczność dobrego przykładu UE. Trudno jest bowiem wciągnąć do gry takie potęgi gospodarcze, jak USA i Chiny czy Indie. Ostatnie wybory w USA dają małe nadzieje na zmianę stanowiska tego państwa. Rola UE jako lokomotywy globalnej w walce z ociepleniem klimatu jak dotąd nie ujawniła się, nawet po propozycjach powiększenia jeszcze do 2020 r. redukcji $\mathrm{CO}_{2}$ o $30 \%$. Pod znakiem zapytania stoi uzyskanie zgody na kolejnych szczytach Ziemi, tym bardziej że coraz większe znaczenie będą miały tu państwa gospodarek wschodzących, gdzie jest inna filozofia rozwoju zrównoważonego i występuje awersja do kosztownych ścieżek rozwoju energetyki.

Jak dotąd, cele redukcyjne $\mathrm{CO}_{2}$ handlu emisjami Unia osiąga nie tyle odzyskując i magazynując ten gaz, czy oszczędzając energię i szerzej wdrażając OZE, ile wykorzystując kryzys i osłabienie produkcji przemysłowej. I tak np., jak podaje Europejska Agencja Środowiska, europejskie emisje $\mathrm{CO}_{2}$ na skutek kryzysu rzeczywiście spadły w 2009 r. o blisko 7\%, pozwalając zbliżyć się do wyznaczonego na 2020 r. celu redukcji emisji o $20 \%{ }^{15}$.

\footnotetext{
${ }_{13}$ Jak skutecznie wdrożyć CCS w Polsce? Ramy finansowe, red. A. Hinc, demoEUROPA, Warszawa 2010, s. 10 i nast.

14 Ibidem.

${ }^{15}$ UE blisko celu redukcji emisji $\mathrm{CO}_{2}$ o 20 proc. w 2020 r., PAP, Warszawa, 10.09.2010.
} 
Generalna ocena polityki energetycznej UE musi uznać słuszność większości założeń i kierunków działania. Niemniej jednak widoczne jest rosnące zaangażowanie Komisji i Parlamentu Europejskiego przede wszystkim w zakresie ustalania celów klimatycznych za wszelką cenę (np. propozycja części państw Unii na szczycie klimatycznym w Kopenhadze zwiększenia do 2020 r. redukcji $\mathrm{CO}_{2}$ o $30 \%$ ). Polityka klimatyczna UE ma znamiona sui generis licytacji pokerowej, z próbami przechytrzenia wewnętrznych i zewnętrznych interesariuszy, czy wręcz bagatelizowania lub ukrywania rzeczywistych kosztów jej realizacji. Jeszcze nie osiągnięto pierwotnych celów wyznaczonych przez obowiązujące dyrektywy, a już następne wyśrubowane cele są formułowane nie tylko dla perspektywy 2020 r., lecz także do 2050 r. Często oznacza to zmianę reguł i zasad w trakcie ich realizacji. Zwykle jednak rosnące zaangażowanie nie jest dobrym doradcą w rozwiązywaniu poważnych problemów, zwłaszcza w sytuacji, gdy UE nie jest samowystarczalna pod względem energetycznym, a przez to ceny energii są tu kluczowym parametrem dla gospodarki. Zależność UE od zewnętrznych dostaw paliw i energii przekracza obecnie 50\% (2010 r.), a docelowo sięgnie $70 \%$ (2030 r.).

Co ciekawe, niektóre rządy podchodzą do tych zmian z wielkim entuzjazmem, natomiast inne wydają się być zaskakiwane radykalnością propozycji. To w pewnym stopniu sugeruje, że polityka klimatyczna UE może być postrzegana jako sui generis mechanizm realizacji interesów gospodarczych niektórych państw UE. Coraz więcej jest głosów, że polityka UE w zakresie celów klimatycznych jest co najmniej wątpliwa. Jest to polityka w dużej części oparta na przekonaniach, a nie na solidnych, merytorycznych argumentach i wiedzy. Ponadto już teraz można stwierdzić, że podstawa tej polityki opiera się zdecydowanie na zdezaktualizowanej bazie informacyjnej (to jest na danych lat 2005-2006). Uznaje się, że „pierwotnym błędem strukturalnym jest hierarchia wsteczna budowy niskoemisyjnej gospodarki w Europie”. Oznacza to, że najpierw wyznacza się cele, a dopiero później zastanawia się nad sposobem ich implementacji. Taki model jest nie do przyjęcia w USA, gdzie stawia się na zarządzanie popytem i podażą oraz na stopniowy benchmarking w dziedzinie nowych technologii. Hierarchia wsteczna ma to do siebie, że po sformułowaniu celów i narzędzi realizacji zaczynają się z jednej strony pojawiać poważne pytania, na które brak prostych odpowiedzi, jak np. skąd pozyskać środki i jak złagodzić skutki wzrostu cen energii, a $\mathrm{z}$ drugiej natomiast - potrzeby bieżącego dostosowywania systemu ad hoc do szybko zmieniających się warunków otoczenia ${ }^{16}$.

Komisja Europejska nie ukrywała, że zmiany tylko dyrektyw ETS i RES mogą przyczynić się do 30\% wzrostu cen energii. Należy zauważyć, że w ostatnich 3 latach

${ }^{16}$ J. Sobański, Wujek Sam potrafi, „Nowa Energia” 2010, nr 2. 
zmieniły się istotnie ogólne parametry ekonomiczno-finansowe i zaopatrzeniowe gospodarki światowej. W latach 2008-2009 gospodarkę światową objął kryzys finansowy i gospodarczy oraz spadek koniunktury. Dopiero w końcu 2009 r. pojawiły się słabe objawy wskazujące na możliwość wychodzenia z kryzysu ważnych gospodarek światowych. Należy również zauważyć, że obiektywnym faktem jest autonomiczny (niezależny od polityki UE) wzrost cen paliw kopalnych, zwłaszcza ropy naftowej, której ceny wprawdzie spadły w okresie 2008-2009 na skutek dekoniunktury, niemniej jednak są już obecnie wyższe w stosunku do okresu, gdy projektowano zmiany dyrektyw ekologicznych i energetycznych. W ślad za tym rosną ceny surowców, materiałów i wyrobów przemysłowych, w tym zwłaszcza materiałów budowlanych, stali i produktów chemicznych.

W rezultacie konsekwentna realizacja polityki ochrony klimatu (opartej na zdezaktualizowanych przesłankach i nie dość dobrze uzasadnionych podstawach merytorycznych) tylko w ramach UE w oderwaniu od światowego rynku ropy naftowej i z pominięciem ważnych gospodarek globalnych jest realnym zagrożeniem dla rozwoju przemysłu w Europie z powodu rosnących cen energii i inflacji oraz utraty konkurencyjności Europy względem reszty świata, a w konsekwencji podtrzymania tempa przenoszenia produkcji poza granice UE. Istnieje także ryzyko, że „ślepa uliczka" ochrony klimatu może się skończyć katastrofą gospodarczą, co w sposób szczególny dotknie państwa „węglowe” i słabsze gospodarczo.

Chiny już dziś spychają Unię Europejską na margines systematycznie i konsekwentnie na kolejnych rynkach produkcyjnych, jedynie Stany Zjednoczone jeszcze próbują się bronić. Serwicyzacja gospodarki UE jako kierunek unowocześnienia gospodarki ma też swoje granice. Rodzi to poważne zagrożenie podatności na zjawiska kryzysowe i niestabilność gospodarczą, czego doświadczyła „usługowa” gospodarka Islandii. Jest to o tyle ważne, że zarówno Stany Zjednoczone, jak i Chiny - jak dotąd - niezbyt aktywnie angażują się w projekty redukcji $\mathrm{CO}_{2}$, a tylko idą w kierunku poprawy efektywności energetycznej i promocji źródeł energii odnawialnej. Nie bez znaczenia jest tu także podłoże ambicjonalne obu tych państw ${ }^{17}$.

Te fakty powodują, że opór wobec polityki klimatycznej stawiają już obecnie nie tylko Polska i kraje Europy Centralnej, lecz także Niemcy i Francja ${ }^{18}$. Sprzeciw zgłaszają zarówno koła gospodarcze i energetyka, jak i regulatorzy sektorów

$17 \mathrm{~W}$ tym kontekście znamiennym faktem jest ujawnienie w przecieku z Wikileaks, że prezydent USA Barack Obama preferuje „patrzeć na wschód, a nie na zachód” i „nie ma żadnych uczuć wobec Europy”. Świat widziany oczami USA to konfrontacja dwóch potęg, w której Europa odgrywa drugoplanową rolę. Prawdziwym partnerem i rozgrywającym są dla amerykańskich władz Chiny.

18 KE przekonuje: obniżyć emisje $\mathrm{CO}_{2}$ o 30 proc. do 2020 r., PAP, Warszawa, 24.05.2010; Unijna komisarz ds. klimatu Connie Hedegaard chce zwiększenia o 10 proc. unijnego celu ograniczenia emisji dwutlenku węgla, „Rzeczpospolita” 13.05.2010. 
energetycznych. Przedstawiciele urzędów regulacji energetyki z Polski, Czech i Niemiec podczas Forum Ekonomicznego 2010 w Krynicy uznali, że:

- dostosowanie się do wymogów polityki klimatycznej UE będzie wymagało wielu wysiłków ze strony państw członkowskich, a nowe kraje UE powinny móc liczyć na solidarność innych państw UE,

- należy się zastanowić nad trybem podejmowania decyzji; obecnie to politycy wyznaczają cele, a potem badany jest wpływ decyzji na gospodarkę, a powinno być odwrotnie: najpierw ocena wpływu politycznych decyzji na gospodarkę, potem wyznaczanie celów,

- sztywne trzymanie się założeń pakietu wywoła wzrost taryf o blisko 20 euro/MWh z konsekwencjami społecznymi i politycznymi,

- tylko niektóre państwa regionu poradzą sobie w perspektywie 2020 r., dla wielu jednak może to oznaczać upadek całych gałęzi gospodarki ${ }^{19}$.

Pakiet 3x20 zmusza kraje opierające energetykę na węglu do znacznie większego wysiłku finansowego niż te, które mają bardziej zróżnicowany bilans energetyczny $\mathrm{z}$ większym udziałem gazu ziemnego, energii jądrowej i energii wodnej ${ }^{20}$.

Zamiana darmowego przydziału pozwoleń na emisję $\mathrm{CO}_{2}$ dla elektrowni (grandfathering) na wymóg ich wykupu od 2013 r. obok swojej restrykcyjności wprowadza nieprzejrzystość i niepewność w energetyce konwencjonalnej. De facto jest to wprowadzony tylnymi drzwiami złożony semipodatek ekologiczny („,podatek podymny”), wprawdzie zwiększający dochody budżetu państwa, ale bezpośrednio podnoszący koszty produkcji energii elektrycznej i cieplnej via nakłady inwestycyjne i wzrost kosztów eksploatacji. Jest to okrężny i bardzo kosztowny sposób zmiany relatywnych cen energii elektrycznej i cieplnej ze źródeł konwencjonalnych w stosunku do energii ze źródeł odnawialnych. Podobny efekt można byłoby osiągnąć za pomocą taniego i prostego podatku ekologicznego (podatku węglowego). Wprowadzenie złożonego sytemu handlu emisjami $\mathrm{CO}_{2} \mathrm{z}$ częściowym grandfatheringiem niewątpliwie wpłynie niekorzystnie także na możliwości rozwoju konkurencji w sektorach energetycznych. Wprowadzenie bowiem restrykcyjnych regulacji ekologicznych utrudni liberalizację i tworzenie konkurencyjnych rynków.

${ }_{19}$ Regulatorzy o polityce klimatycznej UE. Panel „Rok 2050 w energetyce Unii Europejskiej - energy mix oparty na gazie i odnawialnych źródłach energii, bez paliw kopalnych?", CIRE.PL (15.09.2010).

${ }^{20}$ Wpływ pakietu 3x20 na PKB jest zawsze ujemny, aczkolwiek w różny sposób dotyka poszczególne państwa UE. Redukcja $\mathrm{CO}_{2}$ w Polsce musi mieć dużo większy wpływ na PKB niż średnio w UE. Różne symulacje podają, że średnio rocznie stracimy $1 \%$ PKB do 2030 r. Z tym, że do 2020 r. będzie to strata większa, w okresie późniejszym - niższa. Koszty ambicji UE uderzają głównie w Polskę, ponieważ spadek PKB w całej UE do 2020 r. szacuje się na nieco ponad 0,5\%. Trzeba także zauważyć, że koszty redukcji $\mathrm{CO}_{2}$ nie są proporcjonalne do stopnia redukcji. W miarę wzrostu stopnia redukcji jej koszty jednostkowe rosną nieproporcjonalnie szybciej. Stąd też przejście na redukcję 30\%, zwłaszcza na cel 50\%, wymagać będzie niepomiernie wyższych nakładów niż te pierwotnie planowane, co może głębiej odbić się na spadku PKB. 
Pakiet 3x20 stwarza Polsce szczególne problemy, jak w sytuacji specyficznej struktury bilansu pozyskania i zużycia energii pierwotnej pogodzić wynikające z niego zadania klimatyczne z modernizacją kraju i doganianiem UE w kluczowych parametrach rozwoju społeczno-gospodarczego. Oczywistym skutkiem pakietu 3x20 będzie obniżenie konkurencyjności polskiej gospodarki nie tylko w wymiarze globalnym, lecz także wobec gospodarek państw UE. Zasadne są tu pytania K. Żmijewskiego, jaki będzie rzeczywisty wysiłek inwestycyjny Polski i skąd mają pochodzić fundusze na inwestycje ${ }^{21}$.

Należy również liczyć się z faktem, że możliwości finansowania projektów $\mathrm{w}$ ramach pakietu zostaną $\mathrm{w}$ nadchodzącym okresie istotnie ograniczone za względu na pomoc finansową UE dla bankrutujących członków Unii. Fundusze polityki spójności na niskoemisyjne technologie nie wystarczą na pokrycie potrzeb. UE liczy, że dodatkowym źródłem środków mógłby być handel uprawnieniami do emisji $\mathrm{CO}_{2}$ w ramach tzw. AAU. To rozwiązanie popiera Polska, ponieważ w tym zakresie mamy duże nadwyżki uprawnień. Niemniej jednak, jak dotąd, rynek globalny AAU znajduje się $\mathrm{w}$ fazie początkowej, a przy tym jest niepewny, ponieważ nadmiar kredytów grozi załamaniem rynku w okresie planistycznym 2013-2020. Dotychczas Polska uzyskała niewiele środków z tego tytułu. Zaspokojenie ambicji klimatycznych wymagałoby więc dodatkowo obniżenia w ETS liczby darmowych pozwoleń na emisje w latach 2013-2019 w stosunku do obecnej alokacji, rozszerzenia listy sektorów objętych ETS (transport, budownictwo, rolnictwo) oraz wprowadzenia podatku od $\mathrm{CO}_{2}$ (węglowego).

Mimo to w kręgach instytucji UE jak bumerang ciągle pojawia się propozycja obniżenia emisji $\mathrm{CO}_{2}$ do 2020 r. o $30 \%$. Wielką promotorką podwyższenia unijnego celu redukcji emisji $\mathrm{CO}_{2}$ jest komisarz ds. klimatu C. Hedegaard, która przekonuje, że przejście na ambitniejszy cel na skutek wywołanego kryzysem spowolnienia gospodarczego i spadku popytu na energię będzie wymagało mniejszych nakładów niż prognozowano w 2007 r., oraz na jakoby nieznaczący przyrost łącznych kosztów projektu. KE przedstawia wzrost kosztów z około 70 do 80 mld euro rocznie, chociaż są też inne oceny mówiące, że to będzie de facto wzrost z 50 do 80 mld euro. Pomysły tego rodzaju są groźne dla Polski, ponieważ mogą kosztować naszą gospodarkę dodatkowy $1 \mathrm{mld}$ euro rocznie. Już dziś widoczne są negatywne skutki dekarbonizacji - kolejne firmy energetyczne w Polsce rezygnują z planów budowy elektrowni węglowych, bądź zapowiadają wycofanie się z polskiej elektroenergetyki i ciepłownictwa. Trudne do przewidzenia są też reakcje energochłonnych gałęzi przemysłu.

${ }^{21}$ K. Żmijewski, Infrastruktura - remanent XX-lecia, konferencja pt. „Szanse realizacji Pakietu Klimatyczno-Energetycznego", Centrum Prasowe PAP, Warszawa, 13.07.2010. 
Wpływ polityki klimatyczno-energetycznej UE na polską energetykę i gospodarkę był i jest bez wątpienia bardzo silny zarówno przed, jak i po 2004 r. W pierwszym rzędzie konieczne było dostosowania polskiego prawa ochrony środowiska i prawa gospodarczego do wymogów dyrektyw UE. Polska musiała dokonać również zmian organizacyjnych oraz wprowadzić monitoring ekologiczny. Do głównych przepisów prawa zmienionych lub utworzonych pod wpływem wymogów UE należą ustawy - Prawo ochrony środowiska (2000), Prawo energetyczne (1997) oraz ustawy o węższym zakresie przedmiotowym, jak np. ustawa o handlu uprawnieniami do emisji gazów cieplarnianych i innych substancji ${ }^{22}$. Ważne w tym zakresie są dokumenty rządowe, będące skutkiem zmian prawa ekologicznego i energetycznego, m.in. takie, jak: kolejne edycje polityki ekologicznej państwa, Strategia zrównoważonego rozwoju Polski do 2025 roku, Polityka energetyczna Polski do roku 2025, Program dla elektroenergetyki i Polityka dla przemysłu gazu ziemnego.

Ze względu na zmieniające się uwarunkowania zewnętrzne oraz zmiany podejścia do polityki energetycznej i ekologicznej kolejnych rządów, ale również i pośpiech legislacyjny zarówno prawo, jak i dokumenty rządowe szybko się dezaktualizowały, co wymagało częstych nowelizacji czy też przygotowania nowych dokumentów. Problematyka energetyczna dla kolejnych rządów do 2007 r. nie stanowiła specjalnie ważnego pola zainteresowań. Na skutek tego obecny rząd został postawiony w $2008 \mathrm{r}$. przed naprawdę wielkimi wyzwaniami i koniecznością wielu działań na płaszczyźnie krajowej oraz negocjacji z UE. W wyniku intensywnych konsultacji w latach 2008-2010 i po wielu perturbacjach rząd przyjął Politykę energetyczna Polski do $2030 \mathrm{r}$. oraz podjął negocjacje z UE w sprawie złagodzenia warunków pakietu 3×20 dla Polski.

Błędem procesu negocjacji akcesyjnych i harmonizacji prawa była zgoda na wygórowane żądania UE w dziedzinie ochrony środowiska i energetyki oraz brak realistycznego rozpoznania i niedoszacowanie niezbędnych nakładów na realizację poszczególnych dyrektyw i zobowiązań23 ${ }^{23}$ Stąd też sprostanie wymogom UE zarówno przed, jak i po akcesji Polski do UE stanowi źródło podstawowych problemów polskiej polityki energetycznej. Wiele różnych przedsięwzięć inwestycyjnych znajduje się w dalszym ciągu w fazie realizacji, często ze znacznym opóźnieniem czasowym.

Jeszcze większe wyzwania i niewiadome niesie nowa polityka klimatyczno-energetyczna UE. Problem bowiem tkwi w tym, iż zarówno obniżenie emisji $\mathrm{CO}_{2} \mathrm{i}$ innych zanieczyszczeń powietrza, jak i promocja OZE czy też dywersyfikacja dostaw energii nierozerwalnie wiążą się z wysokimi kosztami, przynajmniej w krótkiej i średniej

\footnotetext{
22 Ustawa z dnia 22 grudnia 2004 r. o handlu uprawnieniami do emisji gazów cieplarnianych i innych substancji, DzU nr 281, poz. 2784.

${ }^{23}$ K. Prandecki, Ekonomiczne i prawne problemy ochrony środowiska w Polsce, Instytut Finansów, Warszawa 2006, niepublikowana rozprawa doktorska, rozdział 5.
} 
perspektywie ${ }^{24}$. Ochrona środowiska, bezpieczeństwo energetyczne, efektywność energetyczna czy promocja OZE kosztują i niewiele jest działań w tym zakresie, które dają się zrealizować tanio. W kontekście wymogów UE kluczowe wyzwania dla polskiej energetyki związane są z:

- jednostronnym uzależnieniem elektroenergetyki i ciepłownictwa od węgla,

- złym stanem technicznym i niską efektywnością energetyczną przestarzałych źródeł i sieci elektroenergetyki i ciepłownictwa,

- niedostosowaniem technologicznym elektroenergetyki i ciepłownictwa pod względem osiągnięć emisyjnych,

- przychodem bilansu gazu ziemnego opartym w dużej mierze na dostawach zagranicznych od jednego dostawcy,

- niewielkim zakresem wykorzystania OZE oraz brakiem energetyki jądrowej,

- niską efektywnością energetyczną w obszarze odbioru i użytkowania energii.

Tak więc poza zapewnieniem bezpieczeństwa dostaw gazu ziemnego polska energetyka wymaga ogromnych nakładów inwestycyjnych na modernizację techniczno-ekologiczną majątku produkcyjnego oraz sieci elektroenergetycznych i ciepłowniczych. Energetyka polska potrzebuje również zrealizowania nowych kapitałochłonnych inwestycji w zakresie nowych bloków energetycznych (w tym też jądrowych), rozbudowy transgranicznych połączeń z systemami sąsiedzkimi, zdecentralizowanych inwestycji w biotechnologie energetyczne i energetykę wiatrową oraz budowy nadrzędnej infrastruktury gazowniczej (gazociągi międzynarodowe i terminal LNG $)^{25}$. Większość tych zadań związana jest $z$ energetyką konwencjonalną, jak również z promocją OZE i poprawą efektywności energetycznej.

Energetyka i przemysł w Polsce dokonały wielkiego wysiłku finansowo-technicznego w kierunku realizacji dyrektywy IPPC (pozwolenia zintegrowane). Natomiast nierozwiązanym problemem jest sprostanie wymaganiom dyrektywy LPC, a dotyczącym emisji $\mathrm{SO}_{2}, \mathrm{NO}_{\mathrm{x}}$ i pyłów. Szczególnie trudna sytuacja jest w zakresie redukcji $\mathrm{SO}_{2}$ i $\mathrm{NO}_{\mathrm{x}}{ }^{26}$. Opóźnienia modernizacji elektrowni w zakresie instalacji odsiarczania spalin powodują, że niektóre bloki są już obecnie wyłączane z ruchu ze względu na przekroczenia emisji $\mathrm{SO}_{2}$. Ogólnie ocenia się, że energetyka znajduje się dopiero na półmetku i Polska nie jest w stanie wywiązać się w terminach ze zobowiązań wynikających ze „starych” dyrektyw LPC i NEC, nie mówiąc już problemach wynikających z dyrektywy IED. Nowe zaostrzone wymogi UE mogą doprowadzić do tego, że

\footnotetext{
24 J. Malko, op.cit.

${ }_{25}$ Poprawa efektywności energetycznej w przeważającej mierze odnosi się do zdecentralizowanych działań poza sektorami energetycznymi.

${ }^{26}$ Polskie elektrownie emitują obecnie od $500-550 \mathrm{mg} \mathrm{NO} / \mathrm{m}^{3}$, podczas gdy zgodnie $\mathrm{z}$ normami unijnymi od $2016 \mathrm{r}$. emisja ta nie może przekroczyć poziomu $200 \mathrm{mg} \mathrm{NO} / \mathrm{m}^{3}$. Tylko jedna elektrownia ma instalację spełniającą normy unijne na 2016r. (blok nr 3 w Elektrowni Opole).
} 
wiele dotychczasowych inwestycji ekologicznych w energetyce okaże się chybione i nie uchroni instalacji przed ponowną modernizacją lub wyłączeniami z ruchu.

Dużo problemów polskiej energetyki konwencjonalnej wynika ze zmiany charakteru handlu emisjami $\mathrm{CO}_{2}$ w latach 2008-2020. Przydział pozwoleń $\mathrm{CO}_{2}$ w II fazie ETS (2008-2012) okazał się dla Polski znacznie niższy niż oczekiwano, a także niższy niż w I fazie (2005-2007). Na lata 2008-2012 Polska otrzymała pozwolenia na $208,5 \mathrm{mln}$ t $\mathrm{CO}_{2}$, czyli mniej niż w I fazie $(239,1 \mathrm{mln} \mathrm{t})$ i znacznie mniej niż wnioskowano $(286 \mathrm{mln} \mathrm{t})$. Początkowo oceniano, że polskiej gospodarce może zabraknąć około $30 \mathrm{mln}$ t rocznie uprawnień. To wzbudzało emocje w zakresie sprawiedliwego rozdziału uprawnień między branżami, wydłużając proces uzgodnień na lata 2008-2012. Sprzeczności interesów tkwią między energetyką zawodową (elektrownie i elektrociepłownie) a hutnictwem żelaza i stali, przemysłem cementowym, wapienniczym, rafineryjnym i chemicznym oraz ciepłownictwem komunalnym. Redukcje dotknęły elektrownie i elektrociepłownie zawodowe, ponieważ z przyczyn bilansowych w pozostałych branżach swoboda manewru jest ograniczona. Zagrożenia II fazy ETS wiązano nie tylko z tylko ograniczeniem możliwości produkcyjnych polskiej gospodarki, lecz także prognozami wysokich cen uprawnień na giełdach europejskich oraz podwyżką kar na przekroczenia emisji $\mathrm{CO}_{2}$ z 40 do 100 euro/t.

O ile w I fazie system ETS zbankrutował ze względu na przewymiarowanie darmowych pozwoleń, co spowodowało spadek cen na giełdach do poziomu śladowego, o tyle w II fazie rynek wtórny odbudował się, a ceny pozwoleń są znaczące, niemniej jednak dużo niższe niż przewidywały prognozy. Obecna niska koniunktura gospodarcza łagodzi obciążenie polskich przedsiębiorstw $\mathrm{z}$ tego tytułu.

Zmiany ETS w III fazie (2013-2020) postawiły przed Polską bardzo poważny problem. Propozycja wykupu przez elektrownie $100 \%$ pozwoleń emisyjnych $\mathrm{CO}_{2}$ od 2013 r. mogła je kosztować nawet 5 mld euro rocznie, jako dodatkowe obciążenie energetyki zawodowej do już istniejących ciężarów wynikających z dyrektyw IPPC i LPC oraz z dyrektywy ETS w II fazie. Konsekwencją zmian handlu $\mathrm{CO}_{2}$ byłby natychmiastowy wzrost cen energii elektrycznej o $50-70 \%{ }^{27}$. Niektóre szacunki mówiły nawet o wzroście tych cen po 2012 r. w granicach $70-90 \%$.

Jeśli już obecne ceny energii w Polsce - jeszcze bez znaczącego wpływu pakietu $3 \times 20$ - są relatywnie wysokie, a URE ma problem $z$ uwolnieniem cen energii elektrycznej, to prognozy takiej skali podwyżek postawiały rząd Polski w bardzo trudnej sytuacji ${ }^{28}$. Problemu nie mogły rozwiązać sugestie ad hoc komisarza

\footnotetext{
27 A. Kowalska, op.cit.

${ }^{28}$ Wprawdzie ceny energii elektrycznej dla gospodarstw domowych w Polsce według kursu walutowego znajdują się na średnim poziomie europejskim, jednak według siły nabywczej (PPP) Polska albo ma ceny energii elektrycznej grupy państw o najwyższym poziomie (P. Bergier, B. Pomorska), albo wyprzedza
} 
ds. środowiska S. Dimasa, że na wykupie pozwoleń zarobi budżet państwa, gromadząc w ten sposób fundusze na rekompensaty dla odbiorców wrażliwych. Te środki z założenia powinny wesprzeć inwestycje proekologiczne, a nie pomoc socjalną. Tworzenie programów socjalnych dla szerokiego kręgu gospodarstw domowych jest niebezpieczne ze względu na szybkie rozszerzanie liczby uprawnionych w miarę wzrostu cen energii. Programy socjalne łatwo się wprowadza, trudniej jest później z nich wyjść. Deregulacja cen energii wymaga dopracowania mechanizmu ochrony odbiorców wrażliwych w ramach systemu pomocy społecznej. Ochrona odbiorców wrażliwych poprzez system pomocy społecznej zdejmuje de facto odpowiedzialność za taryfy z przedsiębiorstw energetycznych, obciążając tym administracje samorządowe i ich budżety.

Ostatecznie Polsce udało się, po trudnych negocjacjach, złagodzić warunki wykupu pozwoleń przez elektroenergetykę konwencjonalną poprzez stopniowe dochodzenie do pełnego wykupu w okresie 2013-2020. Nie rozwiązuje to problemów ekonomiczno-finansowych elektroenergetyki i ciepłownictwa, tylko je oddala w czasie. Przyjęte przez UE w grudniu 2010 r. zasady ostatecznego przydziału darmowych uprawnień w III fazie ETS są mimo wszystko niekorzystne zarówno dla polskiej energetyki konwencjonalnej, jak i energochłonnych przemysłów z powodu oparcia referencyjnych wskaźników emisyjności na instalacjach gazowych, a nie na sugerowanych przez Polskę instalacjach węglowych.

Pakiet klimatyczny jest dla Polski rozwiązaniem obiektywnie niekorzystnym w zakresie produkcji energii elektrycznej i cieplnej w źródłach konwencjonalnych. Jednak nie tylko handel $\mathrm{CO}_{2}$ i technologie niskoemisyjne będą w obecnej dekadzie czynnikiem pobudzającym wzrost cen energii. Również modernizacja energetyki, budowa energetyki jądrowej oraz promocja OZE i poprawa efektywności energetycznej będą dodatkowo prowadzić do ogólnego wzrostu cen energii. Przedsięwzięcia te będą wymagały ogromnych nakładów inwestycyjnych i w konsekwencji przełożą się na poziom kosztów eksploatacyjnych, głównie poprzez wzrost kosztów amortyzacji. Czynniki zwiększające wydatki bieżące i koszty paliwa wpłyną znacząco na poziom kosztów zmiennych. Ponadto wspomaganie OZE i efektywności energetycznej za pomocą kolorowych świadectw stanowić będzie dodatkowy akcelerator cen energii. Trudne problemy modernizacji majątku produkcyjnego i sieciowego polskiej elektroenergetyki i ciepłownictwa (zwłaszcza komunalnego) zostaną pogłębione przez dyrektywę IED.

wszystkie państwa Unii (J. Dopke). Lepsza sytuacja występuje w zakresie cen gazu ziemnego. Zob. P. Bergier, B. Pomorska, Czy podwyżki cen energii elektrycznej sa uzasadnione?, „Energia Elektryczna” 2009, nr 3; J. Dopke, Ceny energii dla gospodarstw domowych w Polsce sa najwyższe w Europie, 2008, s. 1-2, www.ogrzewnictwo.home, pdf 


\section{Kierunki rozwoju energetyki konwencjonalnej}

\subsection{Dostosowanie do handlu dwutlenkiem węgla}

Zasadniczym celem ETS jest przyspieszenie dekarbonizacji energetyki i gospodarki, czyli z jednej strony wypychanie węgla jako paliwa w elektrowniach, elektrociepłowniach i ciepłowniach kosztem zwiększenia udziału OZE, gazu ziemnego i paliw płynnych, z drugiej zaś wdrażanie specyficznych technologii, aby uzyskać radykalne obniżenie emisji dwutlenku węgla ${ }^{29}$. Dotyka to szczególnie Polskę ze względu na wysoką emisyjność $\mathrm{CO}_{2}$ polskiej elektroenergetyki ${ }^{30}$. Polska ma trzykrotnie większy udział węgla jako wsadu energetycznego w elektroenergetyce w porównaniu z przodującymi gospodarkami UE. Wskaźnik udziału polskiej elektroenergetyki wynosi 0,94 i jest porównywalny w UE tylko z Estonią $(0,95)$ i Grecją $(0,81)$. Pozostałe państwa mają udziały poniżej $0,65^{31}$. Prowadzi to do wysokiej emisyjności naszej elektroenergetyki. Emisyjność polskiego ciepłownictwa jest nieco niższa ze względu na niższy udział węgla jako paliwa wsadowego $(0,80)^{32}$.

Handel $\mathrm{CO}_{2}$ nie jest zwykłym systemem handlu zanieczyszczeniami, ponieważ natura $\mathrm{CO}_{2}$ nie pozwala na szybkie obniżenie emisji przez inwestycje i postęp techniczny. Technologiczne aspekty redukcji $\mathrm{CO}_{2}$ są daleko trudniejsze niż redukcja emisji $\mathrm{SO}_{2}, \mathrm{NO}_{\mathrm{x}}$ i pyłów. Technologie redukcji $\mathrm{CO}_{2}$ są nowymi rozwiązaniami, dotychczas niepraktykowanymi na skalę przemysłową. Handel $\mathrm{CO}_{2}$ jest mechanizmem wyraźnie przeciwstawnym przedsiębiorczości, zwłaszcza w sytuacji wzrostu gospodarczego.

Ograniczone, jednakże ważne, są osiągnięcia negocjacyjne Polski w sprawie grandfatheringu pozwoleń $\mathrm{CO}_{2}$ w III fazie ETS (2013-2020). Malejące darmowe uprawnienia (z 70\% w 2013 r. do zera w 2020 r.) zagwarantowano tylko tym elektrowniom, które pracowały przed 31 grudnia 2008 r. (pod warunkiem gruntownej

29 J. Janikowski, S. Tokarski, Apel o dekarbonizacje, „Polska Energia” 2009, nr 4.

${ }^{30}$ Emisyjność elektrowni na węgiel jest wyższa niż elektrowni na paliwa gazowego. Bloki gazowe emitują $400 \mathrm{~kg} \mathrm{CO} / \mathrm{MWh}$, natomiast bloki na węgiel kamienny i brunatny odpowiednio 900 i $1200 \mathrm{~kg} \mathrm{CO}_{2} / \mathrm{MWh}$. Różnica między węglem kamiennym a brunatnym wynika z niższej kaloryczności tego ostatniego; do wytworzenia tej samej ilości pary wodnej trzeba spalić więcej węgla brunatnego. Średnia emisyjność elektroenergetyki w Polsce wynosi $1150 \mathrm{~kg} \mathrm{CO} / \mathrm{MWh}$, natomiast w UE-15 - $420 \mathrm{~kg} \mathrm{CO}_{2} / \mathrm{MWh}$. W. Kiełbasa, Gdzie leży klucz do poprawy efektywności zużycia energii elektrycznej w Polsce?, HYDROENERGO, Warszawa 2007, s. 1, www.cire.pl, pdf

${ }_{31}$ M. Barszcz, H. Kaliś, Polityka energetyczna. Zagrożenia dla polskiej gospodarki, „Nowa Energia” 2009, nr 3.

${ }^{32}$ Energetyka cieplna w liczbach - 2008, URE, Warszawa 2009, s. 13; B. Regulski, Potencjalne skutki pakietu klimatyczno-energetycznego dla ciepłownictwa i odbiorców ciepła, Izba Gospodarcza Ciepłownictwo Polskie, Warszawa 2009, s. 3-4, http://www.cire.pl 
modernizacji nakierowanej na redukcję $\mathrm{CO}_{2}$ ), oraz tym, których budowa rozpoczęła się przed $2009 \mathrm{r}$. Nie wszystkie projektowane bloki energetyczne spełniają ten drugi warunek. Dotyczy to m.in. elektrowni: Bełchatów (blok zeroemisyjny 858 MW na węglu brunatnym), Opole (2 bloki po 900 MW), Rybnik (900 MW), Łagisza (460 MW), Blachownia (910 MW), Kozienice (2 bloki nadkrytyczne nr 11 i 12 po 1000 MW w 2014 r. i 2015 r.), Kompanii Węglowej i RWE (blok 750 MW) i Elektrociepłowni Siekierki Vattenfall (blok 480 MW). De facto więc tylko $9500 \mathrm{MW}$ nowych mocy objętych zostanie nieodpłatnym przydziałem uprawnień. Istotnym problemem jest to, czy te nowe moce mają szanse być oddane do eksploatacji przed końcem 2015 r. oraz czy wpisanie do rządowych programów i nadanie im statusu inwestycji celu publicznego da spodziewany efekt w terminowej realizacji projektów.

Handel $\mathrm{CO}_{2}$ wywołuje w energetyce cztery długoterminowe skutki technologiczne, a mianowicie wdrażanie technologii wychwytywania i składowania $\mathrm{CO}_{2}$, rozwój OZE, rozwój źródeł opartych na gazie ziemnym oraz stanowi w warunkach polskich nieoczekiwany bodziec rozwoju energetyki jądrowej.

Technologie CCS stanowią złożony problem techniczny, ponieważ oprócz instalacji wychwytywania (sekwestracji) $\mathrm{CO}_{2}$ wymagać będą urządzeń do przesyłania $\mathrm{i}$ instalacji zatłaczania i składowania w zbiornikach geologicznych. Składowanie $\mathrm{CO}_{2}$ wiąże się z dostępnością przestrzenną i geologiczną oraz bezpieczeństwem magazynowania. Szanse obniżenia $\mathrm{CO}_{2}$ za pomocą technologii CCS w świetle wielu trudności aplikacyjnych, wad eksploatacyjnych i różnych ryzyk wydają się niewielkie i oddalone w czasie. Przy obecnym stanie wiedzy technologiom CCS przypisuje się zbyt dużo oczekiwań i nadziei na skuteczną ochronę klimatu.

Technologie CCS znajdują się in statu nascendi, w zasadzie w fazie badań i jako takie są jeszcze niesprawdzone i nieznana jest ich skuteczność. Technologie CCS są - jak dotąd - bardzo drogie. Przynajmniej tak jest w relacji do innych sposobów obniżania emisji $\mathrm{CO}_{2}$, czyli np. do poprawy efektywności energetycznej, zamiany paliwa wsadowego w procesach energetycznych i rozwoju OZE. Wszystkie konkrety dotyczące technologii CCS są podawane najczęściej w trybie przypuszczającym, oparte bardziej na przekonaniach niż na faktach. Faktem wiele mówiącym jest to, że UE dopiero wdraża program budowy kilkunastu instalacji demonstracyjnych. Stąd też ryzyko ekonomiczne i finansowe realizacji technologicznej redukcji $\mathrm{CO}_{2}$ poprzez CCS jest nieokreślone. Jest pewne, że i po 2020 r. koszty separacji i składowania będą dużo wyższe niż 20 euro/t $\mathrm{CO}_{2}{ }^{33}$. Pokazowy charakter rozwiązań oznacza, że autorzy pomysłu zaprzęgnięcia CCS do walki z $\mathrm{CO}_{2}$ nie do końca są przekonani o wykonalności technicznej i ekonomicznej wymaganych instalacji.

${ }^{33}$ E. Gąsiorowska, J. Piekacz, Wychwytywanie i składowanie $\mathrm{CO}_{2}$ - doświadczenia praktyczne, „Czysta Energia" 2009, nr 3. 
Rozważania o celowości CCS podejmują zazwyczaj aspekty kosztów inwestycyjnych, natomiast pomijają wpływ CCS na poziom kosztów eksploatacji. Szacuje się, że koszty inwestycyjne elektrowni węglowych z programami CCS wzrosną co najmniej o $1 / 3$, natomiast koszty produkcji energii elektrycznej w technologii CCS nawet o $2 / 3^{34}$. Niektóre opracowania podają, że koszt technologii CCS wraz z przesyłem i zatłaczaniem w warunkach polskich może dać przyrost jednostkowego kosztu wytwarzania energii elektrycznej w granicach $100-170 \mathrm{zt} / \mathrm{MWh}^{35}$. Byłby to bardzo poważny wzrost kosztów produkcji energii elektrycznej, przekreślający z góry konkurencyjność elektrowni z pełnym programem CCS.

Niewielka instalacja demonstracyjna wychwytywania $\mathrm{CO}_{2}$ (bez składowania) w Schwarze Pumpe o mocy tylko 30 MW została zbudowana przy wielkim wsparciu finansowym UE i dwukrotnie przekroczonym preliminarzem kosztów. Doświadczenia z projektem Vattenfalla dają pogląd na skalę problemów i konsekwencji ekonomicznych wdrażania CCS na większą skalę ${ }^{36}$.

Technologie CCS znacząco obniżają sprawność wytwarzania energii elektrycznej, przy tym są wysoce energochłonne, a więc są sprzeczne $\mathrm{z}$ wymogami poprawy efektywności energetycznej. Praktycznie technologie CCS obniżają sprawność bloków energetycznych o 10 pkt. proc., co należy uznać za bardzo wysoką stratę, trudną do akceptacji w warunkach walki o oszczędzanie energii ${ }^{37}$.

Mimo mitycznego charakteru technologii zatłaczania $\mathrm{CO}_{2}$ dyrektywa CCS idzie w kierunku ostrych wymogów technicznych dotyczących składowisk oraz zobowiązania nowych instalacji paleniskowych do dysponowania miejscem na urządzenia wychwytywania i kompresji oraz magazynowania $\mathrm{CO}_{2}$, tak aby w przyszłości można było przyłączyć instalacje CCS. Takie rozwiązania regulacyjne dodatkowo ograniczają możliwości rozwoju energetyki węglowej. Wysokie wymagania techniczne wobec składowisk $\mathrm{CO}_{2}$ mogą też wpływać na możliwości lokalizacyjne nowych elektrowni (np. praktycznie uniemożliwi to lokalizację elektrowni na Górnym Śląsku).

Przyjmuje się, że bezemisyjne technologie węglowe $\mathrm{CO}_{2}$ będą dostępne na szerszą skalę dopiero po 2020 r., a być może i później ${ }^{38}$. Oznacza to, że w perspektywie

34 J. Rakowski, Przewidywane możliwości i koszty ograniczania emisji $\mathrm{CO}_{2}$ z elektrowni weglowych, www. cire.pl, pdf (20.07.2008).

35 J. Lewandowski, Pakiet klimatyczno-energetyczny - szansa czy zagrożenie, prezentacja na konferencję pt. „Zmiany klimatu a społeczeństwo”, UKSW, Warszawa, 20.11.2009.

36 Planowano, że koszt inwestycyjny elektrownii pilotażowej w technologii tlenowo-paliwowej w Schwarze Pumpe w Saksonii wyniesie 1,3 mln euro/MW, faktycznie wyniósł on 2,3 mln euro/MW, natomiast wydatki wzrosły z $30 \mathrm{mln}$ euro do $70 \mathrm{mln}$ euro. Vattenfal, CIRE.PL (23.05.2008).

${ }^{37}$ J. Lewandowski, op.cit.

38 J. Malko, H. Wojciechowski, Technologie CCS - od instalacji pilotowych do komercji, „Instal” 2009, nr 3; E. Gąsiorowska, J. Piekacz, op.cit.; E. Rochom, J. Kuper, Płonna nadzieja: dlaczego technologia wychwytywania dwutlenku wegla nie uratuje klimatu, Greenpeace International, Amsterdam 2008, s. 1, www.greenpeace. org/raw/content/poland, pdf 
2020 r. nie będą one miały żadnego znaczenia dla obniżenia $\mathrm{CO}_{2}$. Do tego czasu redukcja $\mathrm{CO}_{2} \mathrm{w}$ energetyce tradycyjnej może być osiągnięta tylko przez substytucję paliw kopalnych, przedsięwzięcia techniczne podnoszące sprawność urządzeń infrastruktury energetycznej i innowacje technologiczne w elektroenergetyce i ciepłownictwie. Jeśli to nie przyniesie sukcesu, spełnienie przez Polskę celu 20\% wymagać będzie zdecydowanego obniżenia produkcji energii elektrycznej i cieplnej w źródłach na węgiel i zastąpienia tego ubytku energią z OZE i oszczędnościami energii. W krańcowym przypadku należy liczyć się z koniecznością pokrycia deficytu importem (o ile import taki będzie możliwy ze względu na ograniczone możliwości systemu przesyłowego), co może jednak oznaczać zachwianie bezpieczeństwa energetycznego kraju i trudności gospodarcze. Jest bowiem już niewiele czasu na przeprowadzenie zmian w strukturze aparatu wytwórczego elektroenergetyki i ciepłownictwa. Praktycznie więc do $2020 \mathrm{r}$. zasadniczy potencjał obniżania emisji $\mathrm{CO}_{2}$ leży w efektywności energetycznej i rozwoju źródeł energii opartych na OZE oraz w zmniejszeniu aktywności gospodarczej.

W Polsce jest wielu zwolenników zaangażowania technologicznego w CCS. Wskazują oni na przyszłe korzyści z rozwoju nowych technologii, naciskając na rząd, aby decydował o kierunkach rozwoju CCS i angażował się w finansowanie projektów CCS. Korzyści te praktycznie jednak nie będą istotne dla polskiej gospodarki, ponieważ technologie CCS zostaną dostarczone przez firmy starej Unii; tam bowiem wcześniej zaczęto pracować nad instalacjami pilotażowymi. Obok Niemiec przodują w tym zakresie: Dania, Norwegia i Szwecja ${ }^{39}$.

Należy zadać pytanie, co będzie, jeśli komercyjne wdrożenia nie zakończą się sukcesem. Kto wtedy zostanie na lodzie i kto zapłaci za eksperymenty technologiczne niesłychanej skali - eksperymenty, których korzyści ekonomiczne są niewyraźne, a korzyści ekologiczne nieistotne. CCS wdrażana tylko w części gospodarki światowej ma to do siebie, że nie jest technologią należącą do strategii typu win-win, a więc na przykład dającą jednocześnie określony efekt ekologiczny (obniżenie emisji $\mathrm{CO}_{2}$ ) oraz poprawiającą konkurencyjność bloków energetycznych. Część inwestycji ekologicznych, w tym również CCS, ma niestety ze swojej istoty naturę technologii końca rury (end of pipe technology), gdzie nie zawsze oczywiste jest wystąpienie efektów wyższych niż poniesione nakłady, a inwestycje (leczące jedynie skutki zanieczyszczenia) nie poprawiają efektywności funkcjonowania firm ${ }^{40}$. W tym zakresie pionierzy dość często płacą słoną cenę za wdrażanie nowych i niesprawdzonych rozwiązań

\footnotetext{
39 E. Gąsiorowska, J. Piekacz, op.cit.; Jak skutecznie wdrożyć CCS w Polsce?, op.cit.

${ }^{40} \mathrm{Ch}$. Demmke, M. Unfried, Tworzenie zdolności do integracji, europejska polityka ochrony środowiska: Wyzwania dla administracji państw członkowskich, Wyższa Szkoła Administracji Publicznej w Białymstoku, Białystok 2005, s. 238.
} 
technologicznych. Stąd też nie wiadomo, czy w promocję technologii CCS zechce się włączyć biznes. Gospodarka innowacyjna CCS jest ryzykowna, a efektywność ekonomiczna inwestycji nie do końca jest określona, ponieważ nie wiadomo, jak będą się kształtować ceny uprawnień emisyjnych. Ceny te są podstawowym parametrem określającym efektywność różnych przedsięwzięć pakietu 3x20, w tym również technologii CCS.

Z tych rozważań płynie wniosek, że nie należy się śpieszyć z wdrażaniem technologii CCS, aby można łatwo wyjść z błędnej ścieżki technologicznej, gdy okaże się, że zmienia się polityka klimatyczna UE. Niewykluczona jest bowiem zmiana tej polityki ze względu na spadek konkurencyjności kluczowych gospodarek UE względem gospodarki amerykańskiej i gospodarek wschodzących ${ }^{41}$. Planowane 2 polskie projekty CCS (Elektrownia Bełchatów, Zakłady Azotowe w Kędzierzynie) na 8 w całej UE to i tak zaangażowanie nadmierne, zwłaszcza w świetle tego, że z powodu kryzysu współfinansowanie inwestycji CCS przez UE nie przekroczy $1 / 3$ niezbędnych nakładów.

Budowa energetyki jądrowej w Polsce jest nie tyle wynikiem przemyślanej strategii rozwoju społeczno-gospodarczego czy polityki przemysłowej, ile procesem wymuszonym strukturą zużycia paliw w energetyce i ograniczeniami wynikającymi z pakietu i ETS. Gdyby nie narzucone trudne warunki pakietu 3x20, w tym restrykcje III fazy ETS, to program energetyki jądrowej nie miałby szans realizacji w ciągu najbliższych 10 lat, a energetyka jądrowa nie stałaby się ważnym priorytetem polityki energetycznej państwa.

Energetyka jądrowa prowadzi do zróżnicowania paliw użytkowanych w energetyce, natomiast nie dywersyfikuje mocy źródeł energii elektrycznej według elastyczności pracy bloków. Mniejsza elastyczność pracy bloków jądrowych w systemie energetycznym oznacza ich ograniczoną regulacyjność. Energetyka jądrowa, wpływając na zmniejszenie rozmiarów emisji $\mathrm{CO}_{2} \mathrm{i}$ innych zanieczyszczeń powietrza atmosferycznego, może nawet pogorszyć strukturę mocy według kryteriów elastyczności. Elektrownie jądrowe są to źródła podstawowe, a więc mało elastyczne, ponieważ ekonomika wymusza ich ruch w warunkach wysokiego obciążenia (load factor). Elektrownie jądrowe ze względu na bezwładność w pewnej mierze pogarszają także konkurencyjność systemowych bloków węglowych, wypierając je z części obciążenia podstawowego (rysunek 1) ${ }^{42}$. Praca nawet nowoczesnych elektrowni jądrowych

${ }^{41}$ J. Lewandowski, op.cit.

42 Nowe generacje bloków jądrowych z reaktorami ciśnieniowymi PWR są bardziej podatne na sterowanie obciążeniem, niemniej jednak regulacja jest tu w dalszym ciągu ograniczona. Po pierwsze, teoretyczne możliwości regulacyjne nie powinny być wykorzystywane ze względu na ekonomikę pracy bardzo drogich bloków jądrowych, która zależy od stopnia obciążenia. Po drugie, najważniejszym ograniczeniem tech- 
musi być wspomagana przez elektrownie szczytowe w systemie energetycznym. W przeciwnym bowiem razie, jeśli bloki jądrowe będą nadmiernie eksploatowane do pokrywania dobowych zmian obciążenia, to nie osiągną niskich kosztów produkcji ${ }^{43}$.

Barierą rozwoju energetyki jądrowej, obok czasochłonności, jest wysoka kapitałochłonność bloków jądrowych, co oznacza, że kluczową kwestią budowy elektrowni jądrowych jest montaż finansowy inwestycji. Nie do końca jest także rozstrzygnięta efektywność ekonomiczna elektrowni jądrowych w porównaniu elektrowniami węglowymi pracującymi nawet w warunkach pełnego wykupu pozwoleń $\mathrm{CO}_{2}$. Efektywność elektrowni jądrowych także zależy w dużym stopniu od poziomu cen uprawnień $\mathrm{CO}_{2}$ na rynku giełdowym.

Większość opracowań wskazuje na przewagę elektrowni jądrowych w zakresie kosztów wytwarzania energii elektrycznej, chociaż są także opinie przeciwne, podważające relatywną przewagę energetyki jądrowej (A. Kassenberg, W. Mielczarski, J. Popczyk) i kierujące uwagę na energetykę rozproszoną i źródła odnawialne. A. Strupczewski na podstawie polskich i zagranicznych szacunków wykazuje zdecydowaną przewagę elektrowni jądrowych nad elektrowniami węglowymi z programem CCS ${ }^{44}$. Podobne stanowisko zajmują Z. Celiński oraz A. Droździel ${ }^{45}$. Większość opracowań podaje, że koszt wytworzenia energii elektrycznej w elektrowniach węglowych i gazowych jest dwa razy wyższy niż w elektrowniach jądrowych. Elektrownie wiatrowe dają produkcję po kosztach trzykrotnie wyższych niż jądrowe.

Koszty zakupu technologii - w tym prac inżynieryjnych, dostaw urządzeń, budowy i rozruchu elektrowni jądrowych - są dwukrotnie wyższe od kosztów elektrowni węglowych, chociaż dużo niższe niż elektrowni wiatrowych. Obecnie nakłady na elektrownię jądrową wynoszą od 3 do $3,5 \mathrm{mln}$ euro/MW, podczas gdy na elektrownię węglową tylko około $1,8 \mathrm{mln}$ euro/MW. W energetyce wiatrowej nakłady inwestycyjne na zakup technologii wynoszą prawie 1,6 mln euro/MW, co przy założeniu wykorzystania mocy znamionowej przez $25 \%$ czasu rocznego daje nakłady na 1 MW mocy efektywnej (średniej w ciągu roku) powyżej $6 \mathrm{mln}$ euro. Przyjmując dla elektrowni jądrowych wskaźnik 3,5 mln euro/MW i współczynnik obciążenia na poziomie 0,9, koszt inwestycyjny elektrowni jądrowej wyniesie 3,9 mln euro/MWe

nicznym szybkiej regulacji mocy siłowni jądrowej jest wzajemne oddziaływanie między koszulką elementu paliwowego a paliwem, grożące uszkodzeniem elementu paliwowego z dalszymi następstwami.

43 J. Kubowski, Problemy wspótpracy elektrowni jądrowych $z$ systemem elektroenergetycznym, „Energetyka" 2010, nr 4.

${ }^{44}$ A. Strupczewski, Czy Polsce opłaci się budowa elektrowni jądrowych?, „Energia Elektryczna” 2009, nr 6; A. Strupczewski, Aspekty ekonomiczne wprowadzenia energetyki jądrowej, „Energetyka Cieplna i Zawodowa” 2009, $\mathrm{nr} 11$.

${ }^{45}$ Z. Celiński, Dlaczego energetyka jądrowa w Polsce?, „Energetyka” 2009, nr 8; A. Droździel, Za 12 lat w Polsce zabraknie prądu. Raport, s. 7, Money.pl 2008 
średniej mocy w ciągu roku. Ponadto elektrownia jądrowa pracuje 60 lat, czyli trzy razy dłużej niż siłownie wiatrowe, co również ma znaczenie.

Pomimo przewagi elektrowni jądrowych nad elektrowniami na OZE, nie są więc one konkurencyjne pod względem nakładów inwestycyjnych wobec elektrowni węglowych, a zwłaszcza gazowych. Dlatego ważna jest terminowa budowa elektrowni jądrowych i eksploatacja przy maksymalnym obciążeniu. To pozwala obniżyć koszt pożyczanego kapitału (oprocentowanie) i koszty produkcji energii elektrycznej ${ }^{46}$.

Rysunek 1. Zależność kosztów produkcji (odniesionych do poziomu 100 dla elektrowni jądrowej) w elektrowniach jądrowych, gazowych i węglowych od rocznego czasu użytkowania mocy instalowanej

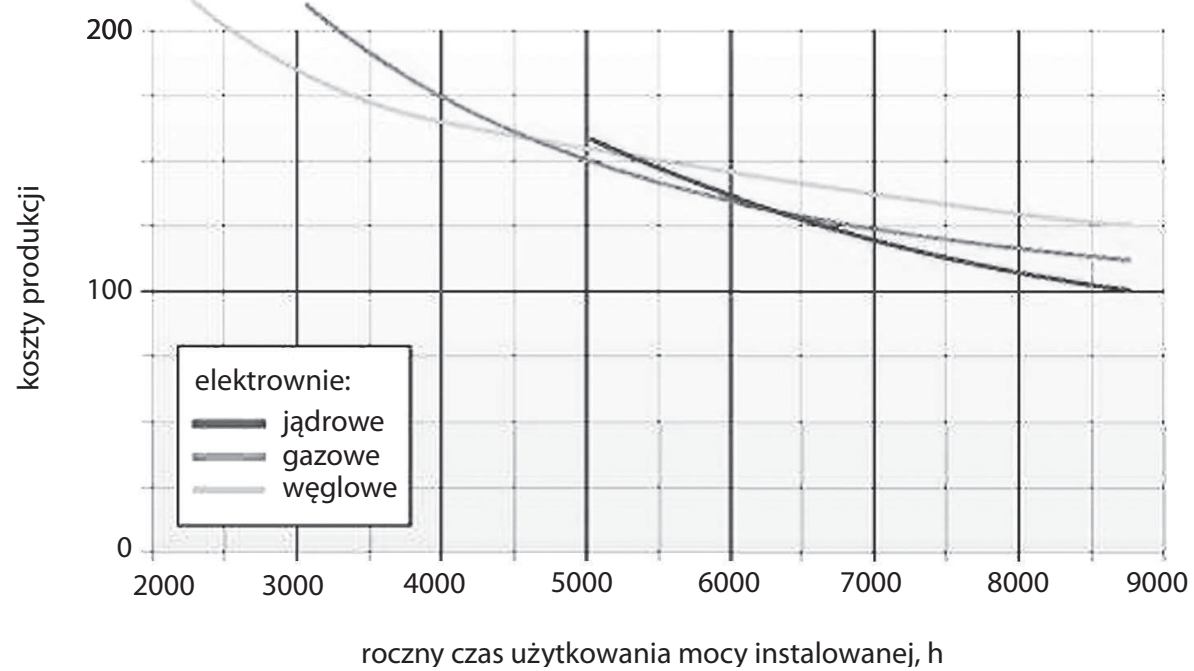

Źródło: J. Kubowski, Problemy wspólpracy elektrowni jądrowych z systemem elektroenergetycznym, „Energetyka" $2010, \mathrm{nr} 4$.

Należy pokreślić, że pozytywnym objawem jest rosnąca społeczna akceptacja elektrowni jądrowych nowej generacji. Wskazują na to m.in. wyniki badań ankietowych Centrum Badania Opinii Społecznej $(\mathrm{CBOS})^{47}$. W związku z tym łatwiej będzie dokonać wyboru lokalizacji tych elektrowni, aczkolwiek należy oczekiwać fundamentalnego sprzeciwu ze strony przedstawicieli organizacji ekologicznych ${ }^{48}$.

${ }^{46}$ A. Strupczewski, Jak zbudować energetykę jadrowa??, „Energetyka Cieplna i Zawodowa” 2010, nr 7-8.

47 O. Fasiecka, Kryzys a energetyka, „Energia Elektryczna” 2009, nr 11.

48 Zob. m.in. Stanowisko Stowarzyszenia Ekologów na rzecz Energii Nuklearnej SEREN wobec twierdzeń dr. Andrzeja Kassenberga opublikowanych w Gazecie Prawnej w dniu 9 kwietnia 2009, SEREN, Warszawa, 10.04. 2009. 
Duże znaczenie w tym zakresie może mieć kampania informacyjna i edukacyjna ujęta jako działanie $7 \mathrm{w}$ Ramowym harmonogramie działań dla energetyki jądrowej ${ }^{49}$. Według stanu na koniec 2010 r. nieoficjalną lokalizacją pierwszej elektrowni jądrowej w Polsce będzie jednak Żarnowiec. Przemawia za tym przede wszystkim istniejąca infrastruktura sieciowa (szyna $400 \mathrm{kV}$ ) oraz zbiornik wody chłodzącej (Jezioro Żarnowieckie). Rozważanymi lokalizacjami są także: Kopań, Choczewo, Lubiatowo-Kopalino oraz jedna lokalizacja wewnątrz kraju - Klempicz.

Szacowany 16\% udział mocy elektrowni jądrowych w systemie elektroenergetycznym w 2030 r. jest wskaźnikiem optymistycznym, który wymagałby budowy i oddania do eksploatacji dwóch elektrowni jądrowych o mocy 3200 MW każda po 2 boki $1600 \mathrm{MW}$, co dałoby przyrost mocy w wysokości $6400 \mathrm{MW}^{50}$. Jak się wydaje, te możliwości istnieją, ale w dłuższym okresie. Pierwsza elektrownia jądrowa zostanie oddana do eksploatacji nie wcześniej niż w 2025 r., natomiast co do drugiej, to nie można z całą pewnością stwierdzić, że zostanie przekazana do eksploatacji przed 2030 r. $^{51}$ Ze względu na niewielki udział w systemie elektroenergetycznym praktycznie energetyka jądrowa może docelowo przyczynić się tylko w ograniczonym stopniu do złagodzenia sytuacji w zakresie emisji $\mathrm{CO}_{2}$ i pozostałych zanieczyszczeń powietrza atmosferycznego po 2025 r. Plany rządowe zakładają, że pierwszy blok jądrowy powstanie w ciągu następnych 12 lat. Niemniej jednak tak krótki okres budowy elektrowni jądrowej może dotyczyć krajów, które mają już doświadczenia w tym zakresie. Natomiast w sytuacji rozpoczynania programu jądrowego przyjmuje się okres do 15 lat $^{52}$. Tym bardziej że jeszcze jest daleko do dostosowania prawa atomowego, organizacji nadzoru i dozoru technicznego, opracowania krajowego planu postępowania $\mathrm{z}$ odpadami promieniotwórczymi i wypalonym paliwem oraz ustanowienia zasad i źródeł finansowania. Toczą się również trudne rozmowy z potencjalnymi dostawcami w sprawie wyboru technologii i warunków zakupu reaktorów.

Niewątpliwym skutkiem zmian technologicznych wywołanych pakietem i handlem $\mathrm{CO}_{2}$ będzie systematyczne ograniczanie znaczenia polskiego górnictwa węglowego. Proces ten jest nieuchronny. W miarę możliwości należy rezygnować z węgla na rzecz gazu ziemnego. Zmiana struktury zużycia paliw w energetyce może być

${ }^{49}$ Ramowy harmonogram działań dla energetyki jądrowej, Minister Gospodarki, Warszawa, lipiec 2009, s. $9-10$.

${ }^{50}$ Budowę dwóch elektrowni jądrowych o mocy 3200 MW planuje Polska Grupa Energetyczna.

${ }^{51}$ Doniesienia o możliwości szybszego uruchomienia elektrowni jądrowej (9-10 lat) należy uznać jednak za chwyty marketingowe firm zainteresowanych wejściem na polski rynek ze swoją technologią.

${ }^{52}$ Według pełnomocnika rządu ds. energetyki jądrowej pierwszy blok elektrowni jądrowej będzie uruchomiony w 2022 r., co wynika z aktualizacji harmonogramu do projektu programu jądrowego. Rząd wstępnie zakładał, że będzie to w 2020 r. Trojanowska: pierwsza elektrownia jądrowa w Polsce ruszy w $2022 \mathrm{r}$., PAP, Warszawa, 12.08.2010 oraz Projekt Programu Polskiej Energetyki Jądrowej, Ministerstwo Gospodarki, Warszawa 2010, s. 10 
bowiem efektywną drogą przybliżenia się do celu $20 \%$ zmniejszenia emisji $\mathrm{CO}_{2}$. Budowa bloków gazowych jest także racjonalna, ponieważ mogą one stanowić amortyzatory stabilności krajowego systemu elektroenergetycznego w związku z rosnącym udziałem mocy elektrowni wiatrowych. Konieczne jest wykorzystanie możliwości związanych z dostępnymi odnawialnymi źródłami energii odnawialnej (OZE). Jednak przy istniejących zasobach paliw pierwotnych nie da się bezboleśnie i szybko przestawić gospodarki energetycznej na inne paliwa kopalne i paliwa alternatywne. Węgiel nawet $\mathrm{w}$ dłuższej perspektywie pozostanie ważnym paliwem dla polskiej energetyki.

\subsection{Modernizacja ekologiczna i technologiczna}

Never ending story polskiej energetyki stanowi walka z emisjami zanieczyszczeń powietrza atmosferycznego. Regulacje UE w tym zakresie ciągle wyprzedzają nasze osiągnięcia i możliwości. Jak wiadomo, dyrektywa o emisjach przemysłowych (IED) zastąpi w 2016r. dotychczasową dyrektywę 96/61/WE (dyrektywa IPPC) oraz dyrektywę 2001/80/WE (dyrektywa LPC). Dyrektywa IED wprowadza restrykcyjne standardy emisji dwutlenku siarki, tlenków azotu i pyłów, ze szczególnym naciskiem na źródła opalane węglem. Zmiany wymogów dla źródeł opalanych gazem są łagodniejsze ${ }^{53}$. W zależności od wielkości i rodzaju źródeł dyrektywa obniża pułapy emisji $\mathrm{SO}_{2}$ od 2,5 do 5 razy, emisji $\mathrm{NO}_{\mathrm{x}}$ odpowiednio 2,5-3 razy, a pyłów od 2 do 6 razy. Nowe rozwiązania dotyczą już nie tylko dużych źródeł (powyżej $50 \mathrm{MW}$ ), lecz także mniejszych (powyżej $20 \mathrm{MW}$ ), w tym również ciepłowni komunalnych.

Nowe normy emisji wykluczają stosowanie prostych metod odsiarczania, odazotowania i odpylania, kwestionując dotychczasowe rozwiązania techniczne, niekiedy nawet te niedawno wdrożone. Formalnie około 1100 kotłów energetycznych w ponad 250 zawodowych, przemysłowych i komunalnych źródłach energii elektrycznej i ciepła czeka doposażenie $\mathrm{w}$ instalacje mokrego odsiarczania spalin, instalacje katalicznego odazotowania oraz wysokosprawne filtry blokowe, względnie wyłączenie z eksploatacji. Prawie 1/3 elektrowni oraz ponad połowa elektrociepłowni i ciepłowni zawodowych i komunalnych nie jest w stanie spełnić warunków dyrektywy IED, z czego znaczna część ze względu na wiek nie nadaje się do modernizacji, tylko do całkowitej wymiany. Jedną z niepożądanych konsekwencji realizacji wymogów dyrektywy IED będzie substytucja ciepła zdalaczynnego przez indywidualne źródła ciepła z negatywnymi skutkami dla środowiska.

\footnotetext{
${ }^{53} \mathrm{~K}$. Badyda, J. Lewandowski, Uwarunkowania wzrostu zapotrzebowanie na gaz dla energetyki i ciepłownictwa, „Rynek Energii” 2009, nr 10.
} 
Dyrektywa IED stwarza pole do ogromnych inwestycji dostosowawczych lub odbudowujących wyłączone zdolności produkcyjne źródeł ciepła. O ile możliwości energetyki zawodowej w tym zakresie są znaczne, to takie zadania dla ciepłownictwa komunalnego są trudne do udźwignięcia. W związku z tym starania polskiego rządu o przesunięcie terminów dla źródeł mniejszych niż 200 MW do 2025 r. były kluczową sprawą negocjacji z UE. Brak derogacji prowadziłby do naprawdę poważnych problemów elektroenergetyki ciepłownictwa konwencjonalnego po $2015 \mathrm{r}$., a już od dnia dzisiejszego czekałby je wielki wysiłek inwestycyjny. Jest oczywiste, że derogacje nie rozwiązują problemów, a tylko je łagodzą w czasie. Trudne do oszacowania są konieczne nakłady na realizację przedsięwzięć w tym zakresie i ich wpływ na ceny energii cieplnej. Dostępne oceny wymieniają kwotę $50 \mathrm{mld} \mathrm{z} \mathrm{z}^{54}$.

W świetle systematycznie zaostrzanych uregulowań UE dotyczących $\mathrm{CO}_{2}$ oraz emisji niektórych zanieczyszczeń powietrza atmosferycznego, a także faktycznego stanu technicznego infrastruktury wytwórczej i sieciowej polska energetyka konwencjonalna wymaga zasadniczych zmian w zakresie odnowienia majątku źródeł energii i sieci energetycznych.

Praktycznie $45 \%$ mocy elektrycznej elektrowni i elektrociepłowni to bloki eksploatowane powyżej 30 lat. Oznacza to, że budowa nowych bloków węglowych i gazowych o łącznej mocy $15 \mathrm{GW}$ powinna pozwolić na zastąpienie starych bloków wycofywanych z eksploatacji. Przyrost nowych mocy powinien dotyczyć elektrowni gazowych i jądrowych.

Jako problem rozwoju mocy w Polsce należy widzieć przede wszystkim nadmierne angażowanie się spółek energetycznych w budowę wielkich bloków energetycznych, zarówno węglowych, jak i gazowych. To nie jest korzystne dla dobrego funkcjonowania na rynku energii elektrycznej, ponieważ jest potrzeba mniejszych i bardziej elastycznych źródeł, w tym przede wszystkim bloków gazowych. Doświadczenia brytyjskie pokazują, że deregulacja rynku energii elektrycznej i handel giełdowy wpływają znacząco na rozwój źródeł elastycznych na gaz i odwrót od źródeł nieelastycznych, czyli węglowych ${ }^{55}$.

O ile inwestycje w nowe bloki węglowe o dużej mocy mają pewne uzasadnienie ze względu na wyższą sprawność, niskie koszty zmienne ruchu oraz chęć uzyskania przewagi konkurencyjnej jako bloków podstawowych systemu elektroenergetycznego, o tyle racjonalność budowy wielkich bloków gazowych jest ograniczona ${ }^{56}$.

\footnotetext{
${ }^{54}$ M. Kozmana, Słony rachunek za czystsze powietrze, „Rzeczpospolita” 01.06.2010.

${ }^{55} \mathrm{~K}$. Hajdrowski, Tworzenie wspólnego europejskiego rynku energii, „Biuletyn URE” 2006, nr 2; D. Newbery, M. Pollitt, The restructuring and privatisation of Britain's CEGB - was it worth it?, „Journal of Industrial Economics" 1997, Nr 3.

${ }^{56} \mathrm{~Np}$. Tauron z PGNiG planuje budowę bloku gazowego o mocy $400 \mathrm{MW}$; Energa, Lotos i PGNiG planują na terenie Gdańska budowę elektrociepłowni gazowej o mocy 200 MW.
} 
Energetyce polskiej brakuje źródeł, które zapewniałyby elastyczną pracę w grafikach obciążeń. Możliwości elastycznej pracy będą szczególnie ważne, gdy liberalizacja europejskiego rynku nabierze rumieńców na skutek wdrożenia zasady TPA w obrotach międzynarodowych. Znaczącym faktem jest to, że dywersyfikacja źródeł energii elektrycznej w Polsce z punktu widzenia elastyczności pracy pozostawia jeszcze wiele do życzenia. Moc bloków gazowych wynosi tylko nieco ponad 2\% mocy zainstalowanej, a udział gazu w produkcji energii elektrycznej jest nieco wyższy i wynosi ponad 3,5\%. W porównaniu $\mathrm{z}$ innymi krajami jest to wynik naprawdę skromny. Polskiej energetyce potrzeba dla bieżącego funkcjonowania w warunkach rynku energii większej dywersyfikacji struktury mocy według kryterium elastyczności ruchu bloków energetycznych.

Problemy polskiej energetyki konwencjonalnej nie sprowadzają się tylko do kwestii źródeł energii elektrycznej i ciepła. Konieczne są także poważne inwestycje sieciowe, zapewniające bezpieczeństwo dostaw energii oraz poprawiające efektywność energetyczną.

W elektroenergetyce główne potrzeby inwestycyjne w zakresie sieci elektrycznych występują w Polsce północno-wschodniej, Polsce południowo-wschodniej oraz na Pomorzu Środkowym i Wschodnim, gdzie sieci są przestarzałe, a ich gęstość pozostawia wiele do życzenia. Na terenie Polski północno-wschodniej występują jeszcze problemy z zasilaniem obszaru w energię elektryczną z systemu przesyłowego, co jest wynikiem słabego wyposażenia w elektrownie i elektrociepłownie. Praktycznie na tym terenie znajduje się tylko jedna elektrownia systemowa (Elektrownia Ostrołęka). Jednym ze sposobów złagodzenia sytuacji tej części Polski jest zakończenie spięcia szyną $400 \mathrm{kV}$ Olsztyna z Białymstokiem oraz budowa połączenia systemów energetycznych Polski i Litwy. W zachodniej części Polski brakuje odcinka sieci przesyłowej 400 kV, łączącej Szczecin z Ostrowem Wielkopolskim (przez Poznań). Ale to nie oznacza, że w innych regionach Polski sytuacja jest dobra. Modernizacji wymagają tu także sieci wysokich, średnich i niskich napięć. System sieciowy należał w ostatnich 20 latach do tej części elektroenergetyki, która niewiele zrobiła w zakresie inwestycji i modernizacji.

W ciepłownictwie komunalnym ponad połowa sieci ciepłowniczej wymaga wymiany na przewody rur preizolowanych ${ }^{57}$. Jest to sieć stara przekraczająca niekiedy wiek 30 lat, która została wykonana metodami tradycyjnymi, czyli układana w technologii kanałowej.

${ }^{57}$ Czekaja nas lata silnego wzrostu, cen ciepła (rozmowa z J. Szymczakiem, prezesem IGCP), „Dziennik Gazeta Prawna" 28.12.2009. 


\subsection{Skutki ekonomiczne i społeczne}

Dla polskiej energetyki skutkami ekonomicznymi pakietu 3x20 i zmiany wymogów emisyjnych są potrzeby ogromnych nakładów inwestycyjnych w energetyce konwencjonalnej i innowacyjnej oraz wzrost kosztów produkcji energii elektrycznej i cieplnej.

Co się tyczy rozmiarów nakładów inwestycyjnych w energetyce, to szacunki w tym zakresie są bardzo rozbieżne. Wydaje się, że szacunki (bez wpływu dyrektywy IED) K. Żmijewskiego w wysokości 100 mld euro, w tym 20 na elektrownie jądrowe, do 2020 r. oraz M. Wilczyńskiego na poziomie 200 mld euro do 2030 r. są zawyżone ${ }^{58}$. Wynika to $\mathrm{z}$ przeszacowania polskiego zaangażowania $\mathrm{w}$ energetykę jądrową i prognozy wysokich cen uprawnień $\mathrm{CO}_{2}$. H. Mikołajuk podaje, że roczne potrzeby inwestycyjne elektroenergetyki wynoszą około $11 \mathrm{mld} \mathrm{zł} \mathrm{w} \mathrm{latach} \mathrm{2007-2015}$ i 15 mld zł w latach 2016-203059. Oznacza to, że łączne nakłady do 2030 r. powinny wynieść ponad $320 \mathrm{mld}$ zł $(96+225)$. Z tego nakłady na źródła konwencjonalne powinny wynosić $4 \mathrm{mld}$ rocznie w pierwszym okresie i $8 \mathrm{mld} \mathrm{w}$ drugim okresie. Potrzeby źródeł OZE i sieci energetycznych praktycznie to rząd nakładów w wysokości po 3 mld zł rocznie na każdą z tych dziedzin. Obserwacja kształtowania się dotychczasowych nakładów rocznych pokazuje, że są one niższe niż prognozy. Faktyczne łączne nakłady inwestycyjne w ostatnich latach wynoszą około $8 \mathrm{mld}$ zł rocz$n^{6} e^{60}$. Agencja Fitch wycenia potrzeby inwestycyjne Polski tylko na moce w elektroenergetyce na poziomie $100 \mathrm{mld}$ zł do $2020 \mathrm{r}^{61}$ Według Ministerstwa Rozwoju Regionalnego do 2025 r. Polska musi zainwestować $120 \mathrm{mld}$ zł, aby odtworzyć i zwiększyć moce energetyczne oraz spełnić wymagania ekologiczne $\mathrm{UE}^{62}$. Z kolei URE przyjmuje nakłady 2008-2030 tylko w same moce źródeł (15 GW wycofanie i 7 GW netto) na poziomie $135 \mathrm{mld}$ zł. Natomiast Europejski Bank Inwestycyjny (EBI) szacuje znacznie wyżej nasze potrzeby inwestycyjne dla całej elektroenergetyki. Według EBI potrzeby inwestycyjne wyniosą prawie $300 \mathrm{mld} \mathrm{zł} \mathrm{w} \mathrm{okresie} \mathrm{do}$ 2020 r., czyli około 70 mld euro (z czego na OZE przypadnie 12 mld euro, na elektrownie jądrowe $-6 \mathrm{mld}$ euro, bloki węglowe - $15 \mathrm{mld}$ euro, sieci $-11 \mathrm{mld}$ euro oraz na CSS - 25 mld euro). Zakłada się, że tylko część inwestycji zostanie sfinansowana

\footnotetext{
${ }^{58}$ Pakiet klimatyczny będzie kosztowat energetykę 100 mld euro, „Rzeczpospolita” 20.04.2009; M. Wilczyński, Polityka ochrony klimatu a koszty utrzymania polskiej rodziny, referat na konferencję pt. „Zmiany klimatu a społeczeństwo", UKSW, Warszawa, 20.11.2009.

${ }^{59}$ H. Mikołajuk, Sprzedaż i wyniki finansowe elektroenergetyki w roku 2008, „Rynek Energii” 2009, nr II.

${ }^{60}$ Ibidem.

${ }^{61}$ Polska energetyka może potrzebować na inwestycje ponad 100 mld zł do 2020 r., PAP, Warszawa, 24.11.2009.

${ }^{62}$ MRR: 120 mld zł potrzebnych na inwestycje w energetyce do 2025 r., PAP, Warszawa, 01.10.2009.
} 
ze środków z handlu $\mathrm{CO}_{2}$. Ocenia się, że to źródło da maksymalnie rocznie około $6 \mathrm{mld}$ zł, czyli około $50 \mathrm{mld}$ zł w całym okresie 2013-2020, aczkolwiek zależy to od funkcjonowania handlu giełdowego $\mathrm{CO}_{2}$ i cen pozwoleń na giełdach. Założeniem tego szacunku jest cena pozwoleń na poziomie 50 euro/t $\mathrm{t}^{63}$. Praktycznie sfinansowanie inwestycji pochodzić będzie prawie w połowie ze środków własnych, a w połowie z emisji akcji, kredytów i emisji obligacji. W związku ze słabszą zdolnością kredytową przedsiębiorstw energetycznych i drogim kredytem wiele firm - według agencji ratingowej Fitch - będzie musiało przesunąć ciężar finansowania zewnętrznego zadłużenia na euroobligacje ${ }^{64}$.

Wydaje się, że rachunek ten można nieco obniżyć w pozycjach energii jądrowej, a zwłaszcza technologii CCS. Przy jednej elektrowni jądrowej (2×1600 MW), której łączny koszt wyniesie około 11 mld euro. Do 2020 r. wystarczą nakłady w wysokości 6 mld euro, ponieważ cała inwestycja nie zostanie zrealizowana do tego czasu ${ }^{65}$. Oszacowanie potrzeb inwestycyjnych w technologie CCS do 2020 r. na poziomie 25 mld euro jest zawyżone, a zaangażowanie w ten kierunek inwestowania praktycznie nie będzie tak daleko idące $\mathrm{i}$ - jak już wskazano - nie powinno być tak wysokie. Zapotrzebowanie na środki finansowe dla sieci przesyłowej i rozdzielczej EBI szacuje na 11 mld euro do 2020 r., niemniej jednak według URE już tylko do końca 2015 r. należałoby w system przesyłowy i rozdział energii elektrycznej zainwestować 28 mld zło6.

Z wymienionych różnych prób oszacowania nakładów inwestycyjnych w polskiej elektroenergetyce można wyciągnąć wniosek, że do 2030 r. konieczne będą nakłady rzędu co najmniej $350 \mathrm{mld}$ zł, czyli roczne nakłady inwestycyjne powinny wynosić minimum 17,5 mld zł. Oznacza to więcej niż podwojenie wysiłku inwestycyjnego w stosunku do mijającej dekady. Rachunek ten nie obejmuje potrzeb inwestycyjnych gazownictwa, efektywności energetycznej oraz skutków dyrektywy IED, które łącznie znacznie przekroczą dodatkowe $100 \mathrm{mld}$ zł. Należy więc liczyć się z tym, że łączne nakłady w energetyce do 2030 r. będą wyższe niż $450 \mathrm{mld}$ zł.

${ }^{63}$ Wkrótce energia $w$ Polsce będzie należała do najdroższej w Europie (rozmowa z B. Jankowskim), „Gazeta Prawna" 22.01.2009.

${ }^{64}$ Polska energetyka..., op.cit.

${ }^{65}$ Najnowsze szacunki Polskiej Grupy Energetycznej (PGE) wskazują, że koszty zakupu technologii, urządzeń i samej budowy wyniosą około 10 mld euro (około 3,3 mld euro za $1000 \mathrm{MW}$ ). Koszt tego przedsięwzięcia będzie wyższy niż pierwotnie zakładano. Ponadto konieczne będzie poniesienie dodatkowych wydatków związanych m.in. z pozyskaniem i przygotowaniem terenu pod budowę, kredytowaniem i przyłączeniem elektrowni do sieci. Według PGE mogą one sięgnąć nawet 1,5 mld euro i koszt całego przedsięwzięcia może przekroczyć $11 \mathrm{mld}$ euro. Pewne różnice mogą też wynikać z tego, jaki oferent zostanie wybrany. Ponad 11 mld euro za pierwsza elektrownię jadrowa w Polsce, „Rzeczpospolita” 02.08.2010; Firmy Korei Płd. $i$ Kanady też chca budować elektrownię atomowa w Polsce, „Rzeczpospolita” 13.09.2010.

${ }^{66}$ Sieci energetyczne sa w bardzo złym stanie, „Dziennik Gazeta Prawna” 18.08.2010. 
Ze społecznego punktu widzenia głównym problemem jest przełożenie nakładów inwestycyjnych i bieżących wydatków sektora energetycznego na ceny energii elektrycznej i cieplnej dla odbiorców końcowych. W szczególności dotyczy to odbiorców domowych. W Polsce ten problem nie jest dostatecznie uświadomiony i niewielu zdaje sobie sprawę z wagi społecznej akceptacji taryf energetycznych (social affordability). Polskie prawo, jak dotąd, nie zawiera definicji odbiorcy słabego ekonomicznie lub odbiorcy wrażliwego, ani definicji ubóstwa energetycznego (fuel poverty). Problem ten najwcześniej uświadomiono sobie w Wielkiej Brytanii. Obecnie jest to już globalny problem rozpatrywany na spotkaniach ministrów energetyki ważniejszych państw świata. Średnie obciążenie budżetu domowego wydatkami na energię powyżej 10\% oznacza według standardów brytyjskich wejście w strefę ubóstwa energetycznego. W większości państw europejskich nie ma jasnych definicji w tym zakresie, natomiast sama UE jest na etapie wypracowywania definicji wskazującej na trudności z utrzymaniem komfortu energetycznego za uczciwą cenę $e^{67}$. W Polsce już w 2005 r. średnie wydatki budżetów domowych wyniosły 10,7\%. Niezależnie od kontekstu energetycznego, jest to także wskaźnik niskiej zamożności polskiego społeczeństwa. Obecnie to obciążenie jest wyższe, ponieważ ceny energii, stosunkowo stabilne w latach 2005-2007, wzrosły (licząc półroczami) o blisko $20 \%$ w 2008 r. i $14 \%$ w 2009 r. ${ }^{68}$ Jest też oczywiste, że ta tendencja wzrostu cen energii utrzyma się w następnych latach. $Z$ różnych ocen wynika, że ceny energii mogą podnieść się o $50-100 \%$, z tym że bliższy prawdy będzie wzrost o $70 \%$. Taki wzrost wpłynie zasadniczo na wzrost obciążenia budżetów domowych. Nawet biorąc pod uwagę skromne szacunki obciążeń budżetów z tytułu wydatków na energię przyjmowane przez Społeczną Radę Konsultacyjną Energetyki z lipca 2008 r. na poziomie $14,5 \%$ w 2030 r., jest to bardzo wysoki wskaźnik przeciętnego obciążenia wydatkami na paliwa i energię.

Wzrost cen energii zatem będzie ostro rzutował na możliwości płatnicze znacznej części gospodarstw domowych, a także na społeczną akceptację zmian taryf energetycznych. Możliwości płatnicze za usługi energetyczne nie mogą być rozpatrywane w izolacji od innych usług publicznych. Trzeba bowiem pamiętać o tym, że tak jak elektroenergetyka i ciepłownictwo domagają się wyższych cen dla gospodarstw domowych, podobnie w zakresie wody i ścieków w Polsce przekracza się poziom wydatków uznawanych w Unii Europejskiej za graniczny, czyli 5\%. Niewykluczone,

\footnotetext{
${ }^{67}$ I. Figaszewska, Ubóstwo energetyczne - co to jest?, „Biuletyn URE” 2009, nr 5.

${ }^{68}$ Rynek energii elektrycznej w Polsce w I pótroczu 2008, Prezes URE, Warszawa 2008, s. 43-44; P. Bergier, B. Pomorska, Czy podwyżki cen energii elektrycznej sq uzasadnione?, „Energia Elektryczna” 2009, nr 3; H. Gabryś, Elektroenergetyka polska 2009, „Energetyka” 2009, nr 11.
} 
że w niedługim czasie dojdą do tego problemu obciążenia gospodarstw domowych z tytułu gospodarki odpadami komunalnymi.

Szybki wzrost cen energii elektrycznej i cieplnej to nie tylko problem i zagrożenie dla gospodarstw domowych, lecz także dla elektrochłonnych i energochłonnych gałęzi przemysłu. Wzrost cen energii powoli powoduje, że polski przemysł kupuje już dziś energię elektryczną po wyższych cenach niż zakłady w Hiszpanii, Francji i Skandynawii ${ }^{69}$. Do poszkodowanych i zagrożonych branż zalicza się hutnictwo żelaza i metali nieżelaznych, przemysł papierniczy, przemysł chemiczny, przemysł cementowo-wapienniczy, ceramikę budowlaną i przemysł szklarski. Huta aluminium Konin i huta Łaziska są przykładami wstrzymania produkcji z powodu wysokich cen energii elektrycznej.

\section{Podsumowanie}

Ekocentryczna polityka energetyczna UE jest bardzo kosztowna i wpływa na wzrost cen energii w całej UE i w poszczególnych państwach wspólnoty. UE nie liczy się z kosztami polityki klimatycznej i bolesnością procesów dostosowawczych, i to mimo dezaktualizacji wskaźników, na których formowano założenia pakietu $3 \times 20$, przetasowań w gospodarce globalnej i trwającego kryzysu. W efekcie polityka klimatyczna UE nie urzeczywistnia celu niskich cen energii, a gospodarka UE traci konkurencyjność międzynarodową. Konsekwentna realizacja nowej polityki energetycznej UE ujętej w pakiecie i „nowych” dyrektywach emisyjnych będzie podtrzymywać te tendencje w następnych dwu dekadach. W nadchodzących latach polityka ta stanie się również sprzeczna z celem strategii Europa 2020, jakim jest ograniczenie wyłączenia społecznego.

Polityka klimatyczno-energetyczna UE w wielu obszarach jest obiektywnie sprzeczna $\mathrm{z}$ interesami i możliwościami polskiej gospodarki i jest postrzegana jako niesprawiedliwa. Dekarbonizacja poprzez rugowanie węgla jako paliwa, stanowiąca bezpośrednią pochodną strategii ochrony klimatu Ziemi, nie służy dobrze polskiej gospodarce i stanowi poważny hamulec naszego rozwoju. Pakiet $3 \times 20$ postawił przed Polską nowe i trudne zadania. Nie ulega wątpliwości, że dla polskiej energetyki lata 2013-2020 są krytyczne zarówno ze względu na konieczność sprostania zewnętrznym wymogom (dyrektywy), jak i potrzeby modernizacji i rozwoju

\footnotetext{
69 Wypowiedź Andrzeja Curyło, dyrektora Zakładów Energetycznych ArcellorMittal Poland, opr. J. Balcewicz, „Energia Gigawat” 2009, nr 11.
} 
infrastruktury energetycznej. Zaostrzenie wymogów emisyjnych prowadzi do wydłużenia tego okresu na następną dekadę.

Polska nie jest w stanie wywiązać się w terminach ze wszystkich dotychczasowych zobowiązań wobec UE w zakresie $\mathrm{SO}_{2}$ i $\mathrm{NO}_{\mathrm{x}}$ związanych ze "starymi” dyrektywami IPPC i LPC ze skutkami dla polskiej gospodarki trudnymi do przecenienia. W nadchodzących latach dochodzą nowe problemy z zarządzaniem $\mathrm{CO}_{2}$ w III fazie ETS oraz zaostrzeniem norm emisyjnych. Sektor energetyczny w dalszym ciągu cechuje się zapóźnieniem technologicznym, co w zderzeniu z wymogami pakietu i dyrektywy IED stawia Polskę w obliczu poważnych trudności gospodarczych. Przede wszystkim chodzi o ich wpływ na ryzyko wyłączeń części źródeł energii, w tym źródeł ciepła, ogrom niezbędnych nakładów inwestycyjnych, ograniczenie możliwości rozwoju kraju, zmniejszenie atrakcyjności lokalizacyjnej kraju dla inwestycji zagranicznych oraz wzrost cen energii, bardzo trudny do absorpcji przez dużą część budżetów domowych. W świetle obecnych i przyszłych uwarunkowań funkcjonowania i rozwoju polskiej energetyki jako całości głównym jej problemem jest i będzie kwestia sfinansowania niezbędnych przedsięwzięć, których rachunek do 2030 r. może zamknąć się w granicach 450-500 mld zł.

$\mathrm{W}$ interesie kraju, w tym również w interesie energetyki konwencjonalnej, było negocjowanie złagodzenia zasad wykupu pozwoleń $\mathrm{CO}_{2}$ w latach 2013-2019 oraz znacznego przesunięcia w czasie obowiązywania wymogów dyrektywy IED. Niemniej jednak Polska uzyskała tylko częściowy sukces w tym zakresie. W pełni uzasadnione są działania rządu w sprawie niedopuszczenia do podjęcia przez UE zobowiązania do $30 \%$ redukcji emisji $\mathrm{CO}_{2}$ do 2020 r. Polska potrzebuje także sprawiedliwego przydziału darmowych pozwoleń na emisję $\mathrm{CO}_{2}$.

Najważniejszymi celami polskiej polityki energetycznej w odniesieniu do energetyki konwencjonalnej w okresie do 2020 r. i dalszej perspektywy powinny być przede wszystkim:

- modernizacja i budowa nowych zawodowych i komunalnych źródeł energii elektrycznej i cieplnej,

- dokończenie inwestycji w instalacje odsiarczania i odazotowania spalin oraz wysokosprawne elektrofiltry pyłowe,

- rozwój energetyki jądrowej oraz szersze wykorzystanie gazu w elektroenergetyce i ciepłownictwie,

- wykorzystanie potencjału gospodarki skojarzonej.

Ze względów bilansowych węgiel w Polsce długo jeszcze pozostawać będzie głównym paliwem $\mathrm{w}$ elektroenergetyce i ciepłownictwie, stanowiąc podstawę naszego bezpieczeństwa energetycznego. Tylko w części zastąpiony zostanie energią jądrową, gazem, OZE i oszczędnością energii. Nie umniejsza to znaczenia rozwoju OZE 
i wielokierunkowego wykorzystania potencjału oszczędzania energii przez poprawę efektywności energetycznej. Są to bowiem skuteczne sposoby obniżania emisji $\mathrm{CO}_{2}$, łagodzenia presji inwestycyjnej w energetyce węglowej oraz unikania deficytów energii w przyszłości. Mimo wysokich kosztów, OZE i poprawa efektywności energetycznej mogą zdecydowanie lepiej przyczynić się do realizacji pakietu niż nie do końca rozpoznane i bardzo drogie technologie CCS. Nadzieje pokładane w CCS są zdecydowanie przeszacowane.

\section{The impact of the EU climate policy on the Polish conventional energy sector}

The study's aim is the analysis and the assessment the EU climate policy and its impacts on the development of conditions of the Polish conventional energy sector. The EU climate policy has a strong influence on Polish energy sector to the year 2020 and further. The position of Polish energy sector is unusual in Europe due to the structure of domestic energy balance. This all with confrontation to the EU aspirations for low carbon economy gives uncertain perspectives for the conventional energy sector. The very ambitious EU climate package and the New Industrial Emissions Directive (IED) led Poland to enormous investments in modernization of coal power and heat plants, very expensive CCS technologies and nuclear power plants. The energy sector isn't able to finance all theseprograms. The climate package and the IED will generate also the increase of energy prices in the next two decades which will be very difficult to absorpt by the national industry and households.

\section{La politique climatique de l'UE et le développement du secteur des énergies classiques en Pologne}

L'objectif de l'étude est d'analyser et d'évaluer la politique climatique de l'UE, ainsi que son impact sur les conditions du développement du secteur des énergies classiques en Pologne. La politique climatique européenne aura une forte influence sur notre secteur énergétique jusqu'en 2020 et dans les années suivantes. La position du secteur polonais est particulière en Europe en raison de la structure de la balance énergétique nationale. Après avoir comparé cette situation aux aspirations de l'UE visant à promouvoir l'économie bas carbone, les perspectives 
pour le secteur des énergies classiques sont incertaines. Le paquet «énergie-climat» de l'UE et la nouvelle directive sur les émissions industrielles (IED) ont contribué à d'énormes investissements dans la modernisation des centrales à charbon et des centrales thermiques, ainsi que dans les technologies de CSC et les centrales nucléaires. Il est impossible pour le secteur de l'énergie de financer tous ces programmes. En outre, le paquet «énergie-climat» et l'IED entraîneront des augmentations importantes des prix au cours des deux prochaines décennies. 